January 2018

\title{
The Icarus Syndrome: How Credit Rating Agencies Lost Their Quasi Immunity
}

Norbert Gaillard

Michael Waibel

University of Cambridge

\section{Recommended Citation}

Norbert Gaillard \& Michael Waibel, The Icarus Syndrome: How Credit Rating Agencies Lost Their Quasi Immunity, 71 SMU L. REV. 1077 (2018)

https://scholar.smu.edu/smulr/vol71/iss4/4

This Article is brought to you for free and open access by the Law Journals at SMU Scholar. It has been accepted for inclusion in SMU Law Review by an authorized administrator of SMU Scholar. For more information, please visit http://digitalrepository.smu.edu. 


\title{
The Icarus Syndrome: How Credit Rating Agencies Lost Their QUASI-IMMUNITY
}

\author{
Norbert J. Gaillard \& Michael Waibel*
}

\begin{abstract}
Subsequent to the 2007-2008 subprime crisis, the SEC and the US Senate discovered that it was common practice for major credit rating agencies (CRAs) to produce inflated and inaccurate structured finance ratings. A host of explanations were posited on how this was able to happen from the "issuer pays" model of CRAs and conflicts of interest to underscoring the $C R A$ 's regulatory license and their ensuing insulation from legal liability. Historically, credit ratings were akin to opinions. However, when courts started to consider structured finance ratings as commercial speech in the 2000s, CRAs became more vulnerable to litigation. This article studies the evolution of the status and the liability regime of CRAs and further argues that they lost their regulatory and judicial "quasi-immunity" over the last decade.
\end{abstract}

\section{TABLE OF CONTENTS}

I. INTRODUCTION . ........................... 1078

II. CREDIT RATING AGENCIES AS GATEKEEPERS OF FINANCIAL MARKETS ....................... 1081

A. The Birth and Development of Credit Rating Agencies ................................. 1081

B. Credit Ratings and Regulatory Rules ......... 1084

1. The Origins of the Mercantile and Credit Rating Agencies and the Transformation of CRAs into De Facto Regulatory Bodies....................... 1085

2. The Incorporation of Credit Ratings in U.S. Rulemaking ............................. 1087

3. Greater Supervision of Rating Agencies and Removal of Statutory References to Ratings ....... 1091

* Norbert J. Gaillard is an economist and independent consultant who specializes in credit ratings. Michael Waibel is a University Senior Lecturer at the University of Cambridge, Co-Deputy Director of the Lauterpacht Centre for International Law, and a fellow of Jesus College. We thank Eyal Benvenisti, Brian Cheffins, Bill Harrington, Eric Kolchinsky, Rick Michalek, and Anna Su for comments on earlier drafts, and Damien Charlotin, Tomas Hamilton, Teresa Mayr, and Puneeth Nagaraj for research assistance. We presented this article at a 3CL Seminar and the Benvenisti-Kingsbury International Law Workshop at the University of Cambridge. 
III. QUASI-IMMUNITY FOR CREDIT RATING

AGENCIES ........................................ 1094

A. Defamation as the Focus of Early Litigation .. 1094

B. Free Speech Protection as the Prevailing Defense for Credit Rating Agencies ............ 1097

C. Litigation Under Securities Law .............. 1100

IV. THE EROSION OF THE FREEDOM OF SPEECH

DEFENSE FOR CRAS ......................... 1101

A. Credit Ratings as a Form of Commercial

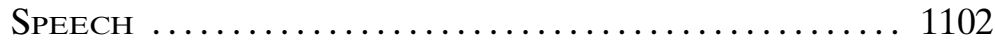

B. The "Public Concern" Condition for First

Amendment Protection ........................ 1104

V. THE GLOBAL FINANCIAL CRISIS AS A CATALYST

FOR RATING AGENCIES ...................... 1106

A. Investor Suits Against Rating Agencies ........ 1107

B. The U.S. Government's Enforcement Actions

Against Rating Agencies ...................... 1110

VI. CONCLUSION .................................. 1115

\section{INTRODUCTION}

$\mathrm{F}$

OLLOWING the subprime crisis of 2007-2008, the U.S. Securities and Exchange Commission (SEC) and the Permanent Subcommittee on Investigations (PSI) of the U.S. Senate investigated the methodologies and practices of major credit rating agencies (CRAs). ${ }^{1}$ They established that CRAs had knowingly produced inflated and inaccurate structured finance (SF) ratings to preserve their market shares and their profits. ${ }^{2}$ Such findings paved the way for an unprecedented wave of regulation and supervision of CRAs, not only in the United States, but also in Europe. ${ }^{3}$

Economists and lawyers have identified three main reasons for why CRAs overrated thousands of mortgage-backed securities (MBS) and collateralized debt obligations (CDOs) and failed in their role as debt

1. Fitch Ratings (Fitch), Moody's Investors Service (Moody's), and Standard \& Poor's (S\&P) are the top three CRAs in the world.

2. See SEC, Summary Report of Issues Identified in the Commission Staff's Examinations of Select Credit Rating Agencies (2008) [hereinafter SEC, Summary REPORT], https://www.sec.gov/news/studies/2008/craexamination070808.pdf [https://perma .cc/7PLQ-3Y79]; SEC, Rep. No. 458, The SEC's Role Regarding and Oversight of Nationally Recognized Statistical Rating Organizations (NRSROs) (2009) [hereinafter SEC, THE SEC's RoLE], https://www.sec.gov/files/report458.pdf [https://perma .cc/M8XW-S9NK]; see also Wall Street and the Financial Crisis: The Role of Credit Rating Agencies: Hearing Before the Subcomm. on Investigations of the S. Comm. on Homeland Sec. and Governmental Affairs, 111th Cong. 1 (2010) [hereinafter Hearing].

3. Dodd-Frank Wall Street Reform and Consumer Protection Act, Pub. L. No. 111203, 124 Stat. 1376 (2010) [hereinafter Dodd-Frank] (codified as amended in sections 12 and 15 U.S.C.); Council Regulation 1060/2009, 2009 O.J. (L 302) 1 (EC), amended by Council Regulation 462/2013, 2013 O.J. (L 146) 1. 
market gatekeepers. ${ }^{4}$ First, some economists and lawyers regard the "issuer pays" model ${ }^{5}$ of CRAs as the main cause of inflated ratings. ${ }^{6}$ As a growing percentage of CRA revenues came from rating lucrative SF products $^{7}$ underwritten by an oligopoly of investment banks, ${ }^{8}$ the rating methodologies of CRAs became laxer and laxer. ${ }^{9}$ A second group identifies conflicts of interest at the CRAs as the main culprit. ${ }^{10} \mathrm{~A}$ third group underscores the regulatory license granted to CRAs by embedding ratings in regulation and their insulation from legal liability. ${ }^{11}$

Although these three causes led CRAs to inflate their SF ratings, U.S. and European legislators have only addressed the third thus far by removing references to credit ratings in regulatory rules ${ }^{12}$ and introducing civil liability regimes for CRAs. ${ }^{13}$ Yet importantly, the SEC has main-

4. Standard \& Poor's global SF annual default and near-default rate for investmentgrade bonds increased by a factor of 315 between 2006 and 2008 , climbing from $0.02 \%$ to $6.31 \%$. Standard \& Poor's, Global Structured Finance Default and Transition Study-1978-2008: Credit Quality Of Global Structured Securities Fell Sharply In 2008 Amid Capital Market Turmoil (2009).

5. From the issuance of the first credit ratings in 1909 to the late 1960s, CRAs' revenues came from investors who purchased rating reports. This was the "investor pays" model. Starting in 1968, S\&P, Moody's, and Fitch charged bond issuers. This shift to the "issuer pays" model enabled CRAs to become more and more profitable.

6. See Jerome Mathis et al., Rating the Raters: Are Reputation Concerns Powerful Enough to Discipline Rating Agencies?, 56 J. Monetary Econ. 657 (2009); John C. Coffee, Jr., Ratings Reform: The Good, the Bad, and the Ugly, 1 Harv. Bus. L. Rev. 231 (2011).

7. In the case of Moody's, the percentage of the SF segment in global revenue increased from $24.6 \%$ in 1997 to $39.4 \%$ in 2007. In the meantime, Moody's revenue soared 434\%. See Moody's Corp., 2007 Annual RePort (2008), http://www.annualreports.com/ HostedData/AnnualReportArchive/m/NYSE_MCO_2007.pdf [https://perma.cc/9SXT4W88]; Moody's Corp., 2000 Annual Report (2001), http://www.annualreports.com/ HostedData/AnnualReportArchive/m/NYSE_MCO_2000.pdf [https://perma.cc/3NY2Y834].

8. In 2007 , twelve financial firms accounted for more than $80 \%$ of the market for mortgage-backed securities (MBS) underwriters. Coffee, supra note 6, at 238.

9. For example, the poorer quality of the SF deals issued between 2006 and 2008 was documented by Efraim Benmelech and Jennifer Dlugosz. See Efraim Benmelech \& Jennifer Dlugosz, The Credit Rating Crisis, 24 NBER Macroeconomics Ann. 161, 161-62 (2010).

10. See Norbert J. Gaillard \& William J. Harrington, Efficient, Commonsense Actions to Foster Accurate Credit Ratings, 11 CAP. Mkts. L.J. 38, 45 (2016); see also Gretchen Morgenson, The Stone Unturned: Credit Ratings, N.Y. Times (Mar. 22, 2014), https://www .nytimes.com/2014/03/23/business/the-stone-unturned-credit-ratings.html.

11. See Caleb Deats, Talk That Isn't Cheap: Does the First Amendment Protect Credit Rating Agencies' Faulty Methodologies from Regulation?, 110 Colum. L. Rev. 1818, 1822-23 (2010); Frank Partnoy, Rethinking Regulation of Credit-Rating Agencies: An Institutional Investor Perspective, 25 J. INT'L BANKING AND FIN. L. 188 (2010). For a seminal analysis on the risks of regulatory dependence on credit ratings, see Frank Partnoy, The Paradox of Credit Ratings, in Richard M. Levich et Al., Ratings, Rating Agencies and the Global Financial System 70-73 (Kluwer Acad. Publishers 2002).

12. Dodd-Frank, tit. IX, § 939 Pub. L. No. 111-203, 124 Stat. 1889 (2010); Council Regulation 1060/2009, art. 5, 2009 O.J. (L 302) 1, 11 (EC).

13. Dodd-Frank, tit. IX, §§ 933, 939 (nullifying SEC Rule 436(g), which exempted CRAs' ratings from being considered part of a registration statement prepared or certified by an expert). For the European Union, see Council Regulation 1060/2009, 2009 O.J. (L 302) 1 (EC), amended by Council Regulation 462/2013, 2013 O.J. (L 146) 1. For the United Kingdom, see Council Regulation 1637/2013, art. 35(a), 2013 O.J. (L 302) 1. 
tained the Nationally Recognized Statistical Rating Organization (NRSRO) designation and continued to supervise the activity of ten CRAs that qualify for this status. ${ }^{14}$ Additionally, some major private investors have continued to rely on ratings for their own internal rules. ${ }^{15}$

However, the most significant development-which is the focus of this article-is that investors and regulators have increasingly brought lawsuits against CRAs, and U.S. courts have started to award damages. For example, in 2009, the U.S. District Court for the Southern District of New York denied First Amendment protection to CRAs for ratings disseminated to a select group of investors. ${ }^{16}$ In 2013, the U.S. Department of Justice sued S\&P for more than $\$ 5$ billion for “(a) mail fraud affecting federally insured financial institutions; (b) wire fraud affecting federally insured financial institutions; and (c) financial institution fraud." ${ }^{17} \mathrm{~S} \& \mathrm{P}$ and the Department of Justice settled this case in February 2015 for $\$ 1.375$ billion-an unprecedented sum for a CRA.

This article studies how the status and the liability regime of CRAs evolved, arguing that CRAs lost their regulatory and judicial "quasi-immunity" over the last decade. Traditionally, these firms enjoyed a degree of protection much higher than their predecessors, mercantile agencies. ${ }^{18}$ First, they were unlikely to be sued for violation of privacy because they assessed the creditworthiness of firms and not individuals. Second, given the opaqueness of the CRAs' methodologies, ${ }^{19}$ negligence was difficult to prove. Third, defamatory allegations were not "credibly" actionable after the shift from the "investor pays" to the "issuer pays" model in the late 1960s-early 1970s. ${ }^{20}$ More fundamentally, CRAs were hardly threatened by libel lawsuits because credit ratings were akin to opinions. ${ }^{21}$ Starting in the 1990s, the emergence of SF products transformed certain rating activities into advisory services, which changed the nature of credit ratings.

Section II discusses the role of CRAs as gatekeepers of financial mar-

14. See infra Section II.B.2. on the concept of NRSRO.

15. Vanguard-one of the world's largest investment companies-continues to trust CRAs. The Vanguard Intermediate-Term Investment-Grade Fund states that it invests in a variety of high-quality fixed-income securities, which it defines simply as "those rated the equivalent of A3 or better by Moody's, or another independent rating agency." VANguard, Vanguard Intermediate-Term Investment-Grade Fund Summary ProSPECTUS 2 (May 27, 2015), https://www.vanguard.com/pub/Pdf/sp71.pdf [https://perma.cc/ 7VU9-AY76].

16. See Abu Dhabi Comm. Bank v. Morgan Stanley \& Co., 651 F. Supp. 2d 155, 175-76 (S.D.N.Y. 2009).

17. Complaint at 1, United States v. McGraw-Hill Cos., No. CV 13-00779 DOC(JCGx), 2013 WL 3762259 (C.D. Cal. July 16, 2013).

18. Mercantile agencies were the first firms that assessed the creditworthiness of individuals and merchants. See infra Section II.B.

19. See Hearing, supra note 2, at 1097.

20. Once debt issuers accepted to pay fees in order to get a rating, they most frequently participated in the rating process.

21. The terms and conditions included in the contracts signed with debt issuers and the subscription terms of use recall that credit ratings are statements of opinion of the relative future credit risk of borrowers and debts and not statements of current or historical fact as to creditworthiness, investment or financial advice, recommendations regarding credit decisions or decisions to purchase, hold or sell any securities. 
kets, ${ }^{22}$ and sheds new light on the regulatory license that the Office of the Comptroller of the Currency (OCC) and the SEC granted them by embedding ratings into regulatory rules and the creation of the NRSRO status. Section III shows that the Free Speech Clause of the First Amendment has traditionally shielded CRAs from litigation. CRAs have even been immune to claims brought under Section 11 of the Securities Act of 1933, which provides for liability for material misstatements and omissions in public offering documents. Section IV argues that the changing character of ratings has eroded the First Amendment protection on which CRAs have traditionally relied. When courts instead started to consider these ratings (especially SF ratings) as commercial speech, they made CRAs more vulnerable to litigation. Section V shows that the subprime crisis of 2007-2008 catalyzed this shift from quasi-immunity to liability, as claims by investors and regulators against CRAs for fraud and negligent misrepresentation fell within the scope of commercial speech. In this context, CRAs had little choice but to reach settlements and pay substantial fines. Section VI concludes.

\section{CREDIT RATING AGENCIES AS GATEKEEPERS OF FINANCIAL MARKETS}

Credit ratings emerged in the first quarter of the twentieth century. They were considered simple and useful tools to assess the creditworthiness of debt issuers. The expansion of capital markets and financial innovation made CRAs increasingly powerful and profitable, particularly from the 1980s onward. They acquired the status of de facto regulators. The growing reliance of investors on credit ratings convinced regulators to incorporate them into regulatory rules, a trend which already started in the 1930s. The reliance on CRAs intensified until policymakers abruptly changed course after the 2007-2008 subprime crisis, when the view gained ground that CRAs had been one of the main causes of the crisis.

\section{A. The Birth and Development of Credit Rating Agencies}

The first ratings appeared in 1909 in Moody's Analyses of Railroad Investments manuals. ${ }^{23}$ These credit risk indicators emerged at a very opportune time. Several factors boosted the demand for rating manuals. As the U.S. corporate bond market boomed, ${ }^{24}$ investors used credit ratings as helpful tools to discriminate between good and bad securities. The first

22. We adopt Professor Coffee's definition of the gatekeeper, i.e., "an agent who acts as a reputational intermediary to assure investors as to the quality of the 'signal' sent by the corporate issuer." John C. Coffee, Jr., Gatekeepers: The Professions And CorPORATE GOVERNANCE 2 (2006).

23. Gilbert Harold, Bond Ratings as an Investment Guide, an Appraisal of Their EfFectiveness 12 (1938).

24. The par amount of outstanding issues soared $112 \%$ between 1900 and 1908. This percentage dwarfs that for 1920-1928 (+46\% only). Authors' computations are based on W. Braddock Hickman \& Elizabeth T. Simpson, Statistical Measures of CorpoRATE Bond Financing Since 190037 (1960). 
blue sky law-aimed at regulating the offering and sale of securities to protect the public from fraud-was enacted in $1911 .{ }^{25}$ In the meantime, growing U.S. savings looked for investment opportunities. Measures such as the development of "baby bonds" 26 encouraged even more households to purchase securities.

Moody's did not have any competitor until 1916, when Poor's issued its first corporate ratings. Standard Statistics and Fitch joined the rating business in 1922 and 1924, respectively. ${ }^{27}$ During the interwar years, no other major firm entered the business and thus, these four CRAs dominated the market for credit ratings. ${ }^{28}$ That said, although they did not issue ratings, several other firms that compiled financial data also competed with Fitch, Moody's, Poor's, and Standard Statistics. For instance, A.M. Best launched its Best's Insurance Reports in 1900, but did not issue ratings until 1928.29 Another example is the short-lived Winkler's Manual of Foreign Corporations, published in 1928 by Max Winkler, who had just left Moody's, but previously oversaw sovereign and municipal ratings. ${ }^{30}$ Thus, from the beginning, the credit rating business had an oligopolistic character. In 1941, the industry became more concentrated when Poor's and Standard Statistics merged to form Standard \& Poor's. The structure of the credit rating industry has not substantially evolved since then.

At the end of 2016, the three main CRAs, Fitch, ${ }^{31}$ Moody's, ${ }^{32}$ and $\mathrm{S} \& \mathrm{P},{ }^{33}$ accounted for $96 \%$ of the world market for credit ratings. ${ }^{34}$ Fitch accounted for just over 300,000 ratings, Moody's for 780,000, and S\&P for nearly 1.12 million ratings. ${ }^{35}$ The profitability of the three main CRAs has been high for many years: their 2016 operating margins reached $45 \%$, $18 \%$, and $50 \%$, respectively. ${ }^{36}$ There are three principal reasons for

25. Jonathan R. Macey \& Geoffrey P. Miller, Origin of the Blue Sky Laws, 70 Tex. L. REv. 347, 352-64 (1991).

26. These baby bonds "allowed all Americans the opportunity to invest even small amounts of money in a government-backed security." Peter Tufano \& Daniel Schneider, Reinventing Savings Bonds 11 (Harvard Bus. Sch., Working Paper No. 06-017, 2005), https:/ /www.hbs.edu/faculty/Publication \%20Files/06-017.pdf [https://perma.cc/MN5G-ELCX].

27. Marc Flandreau et al., To err is human: US rating agencies and the interwar foreign government debt crisis, 15 Eur. Rev. EcON. Hist. 495, 506-08 (2011).

28. HAROLD, supra note 23.

29. Chronology of Events, A.M. BEst, http://www.ambest.com/about/ambchronology .pdf [https://perma.cc/9LPZ-P7LT] (last visited Aug. 4, 2018).

30. Norbert Gaillard, A Century of Sovereign Ratings 32 (2011).

31. Fitch merged with IBCA in 1997 to form Fitch IBCA. Since the purchase of Duff \& Phelps and Thomson Financial BankWatch in 2000, the firm has operated as Fitch Ratings. Fimalac and Hearst own Fitch. See Norbert Gaillard, Les Agences de NotATION 9-10 (2010).

32. Moody's is a company traded on the New York Stock Exchange.

33. S\&P is a subsidiary of McGraw Hill Financial.

34. Authors' calculations are based on the SEC. SEC, Annual Report on Nationally Recognized Statistical Rating Organizations 8 (2017), https://www.sec.gov/ ocr/reportspubs/annual-reports/2017-annual-report-on-nrsros.pdf [https://perma.cc/R4XX$8 \mathrm{CTW}]$.

35. Id.

36. Fimalac, 2016 Annual Report (2017), http://www.fimalac.com/items/files/f5ecf3 7beb048fc109c9b760808cb432_FIMALAC-Rapport-annuel-exercice-2016-english-ver sion.pdf [https://perma.cc/6N4E-TL8P]; MoOdy's CORP., 2016 AnNuAl RePORT (2017), 
CRA's commercial success.

The first reason is the growth of bond markets. The sovereign rating business illustrates how growing sovereign bond markets around the world provided CRAs with more governments to rate. CRAs first assigned sovereign ratings in 1918, when many states had issued securities to finance World War I. With the advent of the Great Depression and World War II, sovereign debt markets dried up and the number of rated foreign government bonds plummeted from one hundred twenty in 1929 to sixty-four in $1940 .{ }^{37}$ Sovereign ratings did not resume in earnest until the financial globalization of the 1980s-1990s took hold. ${ }^{38}$

The second reason is the growing reliance of U.S. (and international) ${ }^{39}$ investors on ratings. ${ }^{40}$ They started embedding credit ratings into their investment rules as early as the $1920 \mathrm{~s} .{ }^{41}$ The incorporation of ratings into investment rules has become standard practice among U.S. and international investors. Such investment rules include setting maximum portfolio shares by rating category, maximum single-security exposure by rating category, minimum requirements for bond purchases, retention guidelines for downgraded securities that no longer meet eligibility guidelines, performance benchmarking relative to ratings-based bond indices, and/or underpinning discussions between fund managers and clients, ${ }^{42}$ forecasters ${ }^{43}$ and U.S. courts. ${ }^{44}$ Others have also used the research output of ma-

http://s21.q4cdn.com/431035000/files/doc_financials/annual/2016/2016-Annual-Report-vFI NAL.pdf [https://perma.cc/VSG2-KPU6]; S\&P Global, 2016 AnnUAL RePORT (2017), http://investor.spglobal.com/Cache/1500096882.pdf?O=PDF\&T=\&Y=\&D=\&FID=150009 $6882 \&$ iid $=4023623$ [https://perma.cc/AM8A-T6WS]. The lower profitability posted by Moody's reflects an $\$ 864$ million charge pursuant to a settlement agreement with the U.S. Department of Justice and the attorneys general of twenty-one U.S. states and the District of Columbia. See infra Section IV.B.

37. GAILlARD, supra note 30, at 4-5. These figures only include USD and GBP sovereign bonds listed on the New York Stock Exchange (NYSE).

38. See id. at 8-10; see also Norbert Gaillard, What Is the Value of Sovereign Ratings?, 15 German Econ. Rev. 208, 209 (2014).

39. Financial globalization starting in the 1980s increased the reliance by investors on credit ratings in the United States and spread to many other countries. See Timothy J. Sinclair, The New Masters of Capital: American Bond Rating Agencies and the Politics of Creditworthiness (2005); Bank for International Settlements, Stocktaking on the Use of CRedit Ratings 1-119 (2009) [hereinafter BIS], https:// www.bis.org/publ/joint22.pdf [https://perma.cc/NAX2-2JY5].

40. The reputation of CRAs depends on the quality of the ratings they assign. See Frank Partnoy, The Siskel and Ebert of Financial Markets?: Two Thumbs Down for the Credit Rating Agencies, 77 W Ash. U. L.Q. 619, 628-36 (1999); Steven L. Schwarcz, Private Ordering of Public Markets: The Rating Agency Paradox, 2002 U. Ill. L. Rev. 1, 14 (2002).

41. Leland Rex Robinson, Investment Trust Organization and Management 557-58 (1929). It took a decade for regulators to emulate investors' reliance on ratings by embedding them in regulatory rules. However, this embedding in regulatory rules proved durable, and regulators only rolled it back from 2010 onwards.

42. Richard Cantor et al., The Use of Credit Ratings in Investment Management in the U.S. and Europe, 17 J. Fixed InCOME 13, 15 (2007).

43. Moody's and Standard Statistics surveys were particularly popular as early as the 1920s. See generally Garfield V. Cox, An Appraisal of American Business ForeCASTS (1929).

44. The number of references to Moody's, Poor's, and Standard Statistics reports in U.S. court decisions grew strongly from the 1910s. See Marc Flandreau \& Joanna Kinga 
jor CRAs in U.S. court cases.

Third, the shift in the business model of CRAs towards the issuer-pays model in the late 1960s boosted their profits. Until then, revenues came from investors who purchased rating reports. In 1968, after a controversy with the city of New York, S\&P decided to charge bond issuers for "the cost of supporting the staff required to perform rating functions." 45 Moody's followed suit in $1970^{46}$ and the revenues and profits of both companies soared within a few years. ${ }^{47}$ During the following decades, CRAs developed annual fee arrangements ${ }^{48}$ and charged increasingly higher fees ${ }^{49}$ to captive bond issuers who were legally bound to obtain a rating. ${ }^{50}$

\section{B. Credit Ratings and Regulatory Rules}

The three characteristics of a CRA are (i) the public accessibility and widespread dissemination of its ratings, (ii) its evaluation of the issuer's credit risk based on models of some kind, and (iii) the payment of a fee by the issuer or market participants to the CRA. Credit ratings are visible for the market and the public at large-even if one has to pay a reasonable fee to the CRA to obtain the underlying rating report. ${ }^{51}$ U.S. law defines a CRA as any person

(A) engaged in the business of issuing credit ratings on the Internet or through another readily accessible means, for free or for a reasonable fee, but does not include a commercial credit reporting company;

Sławatyniec, Understanding rating addiction: US courts and the origins of rating agencies' regulatory license (1900-1940), 20 Fin. Hist. REv. 237, 241-43 (2013).

45. Brenton W. Harries, Standard \& Poor's Corporation New Policy on Rating Municipal Bonds, 24 Fin. Analysts J. 68, 68-71 (1968).

46. See generally Moody's to Charge for Corporate Ratings, But Rival Standard \& Poor's to Hold Off, Wall St. J., Oct. 1, 1970.

47. See generally Michael L. Geczi, The Rating Game, Wall St. J., Oct. 26, 1976. Warren Buffet's Berkshire Hathaway Corporation bought Moody's stock in 2000, and has held more than twelve million of Moody's outstanding stock ever since. See Reports, BERKSHIRE HATHAWAY, http://www.berkshirehathaway.com/reports.html, [https://perma.cc/ 5BGA-VBUC] (last visited Aug. 4, 2018).

48. Nonexistent in 1989, these relationship-based fees accounted for $36 \%$ of Moody's total revenue in 2000. Moody's Corp., 2000 Annual Report 13 (2001). These ancillary business operations contributed to change the nature of the speech delivered by CRAs. See infra Section III.A. According to the SEC, they still present potential conflicts of interest. See SEC, Report to Congress: Credit Rating Agency Independence Study 18 (2013), https://www.sec.gov/news/studies/2013/credit-rating-agency-independence-study2013.pdf [https://perma.cc/C4FN-DH42].

49. For example, fees charged for structured finance deals represented twelve basis points (bps) in 2007 compared to 4-5 bps in 1995. Richard House, Ratings Trouble, 29 Institutional Inv. 245, 245-49 (Oct. 1995). Richard Tomlinson \& David Evans, CDO Boom Masks Subprime Losses, Abetted by S\&P, Moody's, Fitch, Bloomberg (May 31, 2007), https://www.bloomberg.com/news/articles/2007-05-31/cdo-boom-masks-subprimelosses-abetted-by-sp-moodys-fitch [https://perma.cc/6QGJ-J3FA].

50. BIS, supra note 39, at 29-118. See Partnoy, supra note 11, at 74-75.

51. Notably, the commercial credit reporting companies examined in the next section are not CRAs because they do not assign publicly available ratings to issuers, but rather evaluate the creditworthiness of a debtor for a more limited set of recipients. 
(B) employing either a quantitative or qualitative model, or both, to determine credit ratings; and

(C) receiving fees from either issuers, investors, or other market participants, or a combination thereof. ${ }^{52}$

The first sub-section considers the origins of CRAs as well as their precursors, "mercantile agencies," and discusses their emergence as de facto regulatory bodies for capital markets. The second sub-section considers how the increasing reference in regulatory rules to credit ratings cemented their status as market gatekeepers and further amplified the use of ratings by U.S. and international investors. The third sub-section documents how the subprime crisis led to a new paradigm, which convinced U.S. regulators to remove references to credit ratings from regulatory rules.

\section{The Origins of the Mercantile and Credit Rating Agencies and the Transformation of CRAs into De Facto Regulatory Bodies}

As we saw in the previous sub-section, credit rating agencies are a twentieth century phenomenon. Their precursors in the nineteenth century were the so-called mercantile agencies. In 1841, Lewis Tappan formed "The Mercantile Agency," the first credit reporting agency. In 1849, John Bradstreet, his competitor, established the "Bradstreet Agency." ${ }^{3}$ Credit reporting agencies (or mercantile agencies) provided reports on the credit standing of individuals and enterprises, whereas CRAs focus on assessing the creditworthiness of bond issuers. While banks and other businesses relied on credit reporting agencies to judge whether they should extend credit, or enter into another type of transaction, the focus of CRAs has historically been on providing an independent assessment of issuers on the (public) debt markets for the benefit of a dispersed and numerous potential bondholders. ${ }^{54}$

Both mercantile agencies and CRAs feature the term "agency" in their name. The founders of mercantile agencies did not choose the name "agency" to mimic administrative agencies established by Congress. ${ }^{55}$

52. 15 U.S.C. $\S 78 c(a)(61)(2012)$.

53. James H. Madison, The Evolution of Commercial Credit Reporting Agencies in Nineteenth-Century America, 48 Bus. Hist. Rev. 164, 168 (1974).

54. As we show below, ratings of SF products - a key activity of CRAs in the 1990s and 2000s - were not for the benefit of numerous - a factor that led the court post-2010 to qualify them as "commercial speech" rather than as "political speech" benefitting from plenary First Amendment protection.

55. Plainly, neither is an administrative agency, in the formal sense. In U.S. administrative law, an administrative agency is an independent sub-branch of government set up by a legislature to implement laws. Agencies require an enabling act by Congress or a state legislature. Congress, or a state legislature, creates the agency and vests it with specific powers. Administrative Agency, Black's LAW DictionARy (6th ed. 1990) ("A governmental body charged with administering and implementing particular legislation. The term 'agency' includes any department, independent establishment, commission, administration, authority, board or bureau of the United States or any corporation in which the United States has a proprietary interest, unless the context shows that such term was intended to be used in a more limited sense."). 
Lewis Tappan may have envisaged a national agency with broad geographical coverage, and perhaps it fitted his image of the company to name it accordingly. More likely, the term "agency" goes back to the organizational structure of credit reporting agencies. Subscribers to the Mercantile Agency requested information about actual or potential furnishers, clients, or debtors. Lewis Tappan's business model relied on a large network of correspondents or agents. ${ }^{56}$ These agents played a key role in reporting on the creditworthiness of businesspersons and companies from across the United States. This is evident from the volumes of handwritten credit reports of R.G. Dun \& Company (the successor company to the Mercantile Agency); 57 they contained not only personal, commercial, and financial information on businesspersons, but also opinions on their creditworthiness.

CRAs have been privately owned entities since their establishment in the early twentieth century. Unlike Lewis Tappan's company (which, as we saw above, he called Mercantile Agency from its foundation), Fitch, Moody's, Poor's, and Standard Statistics did not call themselves "agencies" during the first two decades of their activities. ${ }^{58}$ Similarly, the Comptroller of the Currency did not mention the concept of agency in the two regulatory rules that incorporated credit ratings in 1931 and $1936 .{ }^{59}$ The OCC only cited the names of the major firms, whose ratings investors could use, and referred simply to the "recognized rating manuals." 60

In fact, the expressions "credit rating agency" and "rating agency" did not begin to spread in banking 61 and academic circles ${ }^{62}$ until the mid1930s. It coincided with the height of the New Deal and the birth of the modern administrative state. It may have reflected the contemporaneous opinion that CRAs had become de facto regulators. Morton aptly summarized this view as follows:

The Banking Act of 1935 had in effect transferred the responsibility for deciding upon the classes of securities to be purchased to governmental agencies, which in turn have delegated it to private institutions: Fitch, Moody, Poor, and Standard Statistics. ${ }^{63}$

56. In 1851, the Mercantile Agency depended on nearly 2,000 correspondents to prepare reports. Madison, supra note 53, at 168.

57. R.G. Dun \& Co., R.G. Dun \& Co. Credit Reports Collection (n.d.) (archived with the Baker Library, Harvard Business School).

58. The four firms primarily emphasized their expertise in statistical and rating services to investors. See Gaillard, supra note 30, at 4-5.

59. See infra Section II.B.2. 1931).

60. Mimeographed Ruling by J. W. Pole, then Comptroller of the Currency (Aug. 29,

61. See Security Regulations Opposed by Bankers, Wall ST. J., June 25, 1936; HaROLD, supra note 23 , at 28.

62. See Raymond W. Coleman, Pledged Revenue as Security for Government Bonds, 26 Am. Econ. Rev. 667, 670 (1936); Melchior Palyi, Bank Portfolios and the Control of the Capital Market, 11 J. Bus. U. CHI. 70, 70-73 (1938); Harold, supra note 23, at 34; Walter A. Morton, Liquidity and Solvency, 29 Am. Econ. Rev. 272, 275 (1939).

63. Morton, supra note 62, at 277 (using the terms "private agencies" and "rating agencies" interchangeably). 
The reference to S\&P's, Moody's, and Fitch as credit rating agencies contributed to giving ratings a quasi-regulatory imprimatur and facilitated the widespread reliance on ratings by government agencies (such as the SEC) and by investors.

\section{The Incorporation of Credit Ratings in U.S. Rulemaking}

As mentioned in the introduction, the reliance on credit ratings takes two forms. First, private investors rely on ratings through their own internal rules. Historically, this type of reliance began in the 1920 s, but continues to date. Second, public regulators incorporate ratings into regulatory rules. This practice started in the 1930s and became entrenched from the 1980s onward. But regulators abruptly changed course in 2010, and for the most part removed references to ratings from their regulatory rules. This section focuses on the second type of reliance.

Ratings became more central to decisions of investors in part through rulemaking by U.S. regulators that referred to ratings. In 1931, the OCC enacted the very first rule that incorporated ratings. ${ }^{64}$ Issued at a time when the U.S. bond market was bearish, this rule indicated that banks had to value their portfolios as follows: they were obliged to report U.S. government and municipal bonds as well as other domestic and foreign securities assigned the four highest ratings (Aaa/AAA, Aa/AA, A/A and $\mathrm{Baa} / \mathrm{BBB}$ ) at face value. In contrast, domestic and foreign securities were rated $\mathrm{Ba} / \mathrm{BB}$ and below at market value. According to the OCC, the rationale for this rule was that high-grade bonds might otherwise be unfairly depreciated.65 In fact, the rule only institutionalized an already widespread practice among U.S. banks. ${ }^{66}$ As early as 1930, the OCC had allowed banks to enter high-grade bonds in their books at face value so that they could carry higher cash reserves. ${ }^{67}$

In 1936, the OCC enacted a second rule that referred to credit ratings. ${ }^{68}$ The Comptroller of the Currency established that U.S. banks could hold only securities rated in the top four rating categories. U.S. government and municipal bonds were outside the ambit of the rule. ${ }^{69}$ This new rule applied to prohibit holdings of "speculative" grade and defaulting bonds. However, the OCC refused to define the term "specula-

64. Mimeographed Ruling by J. W. Pole, Comptroller of the Currency (Aug. 29, 1931).

65. See 75\% of Bank Bond Valuations Safe, Wall St. J., Sept. 12, 1931.

66. See Bond Fluctuations Ignored by Banks, WAsh. Post, Sept. 11, 1931.

67. Gustav Osterhus, Flaw-Tester for Bond Lists, 29 Am. BANKers Ass'N J. 67, 67-68 (1931); see also Pierre Penet, Calculating and Governing Risk in Times of Crisis: The Role of Credit Ratings in Regulatory Reasoning and Legal Change, 84 ENTERPRISES ET HistoIrE 162, 162-63 (2016).

68. See New Set of Rules Further Limits Bank Investments, Wall ST. J., Feb. 27, 1936.

69. The rationale for this decision may be that regulators considered these domestic securities to be safe. In 1929, all CRAs assigned U.S. government bonds the highest rating, while $95 \%$ of U.S. state and local governments were ranked in the top three rating categories. The U.S. government did not default during the Great Depression, but 264 state and local government securities defaulted, and $87 \%$ of them were rated A or higher by Moody's in 1929. See Gaillard, supra note 30, at 39; George H. Hempel, The Postwar Quality of STate And Local Debt 108-109 (1971). 
tive"70 and even mitigated the initial rule, admitting that banks could purchase speculative bonds if they could prove that the risk of default of such securities was low. ${ }^{71}$ This decision to mitigate the rule was linked to lobbying by banks. According to them, these "private rating agencies" had inadequate staff to devote sufficient time to research, with the result that the banks' own ratings differed from those of the agencies. Bankers also considered that the delegation to these firms of the judgment as to what constitutes a sound investment was not warranted by their ability to anticipate crises. ${ }^{72}$

After World War II, the United States made further rules on ratings. For instance, the National Association of Insurance Commissioners (NAIC) imposed higher capital requirements on insurers' lower-rated bonds in $1951 .^{73}$ The SEC "imposed higher capital haircuts on broker/ dealers'" speculative-grade securities (Rule 15c3-1) and eased disclosure requirements for investment-grade bonds in 1975 and 1982, respectively. ${ }^{74}$

With the advent of financial globalization in the 1980s, getting a credit rating became crucial for debt issuers willing to access capital markets and borrow from investment funds, which had no internal credit risk assessment comparable to those that banks used. This led to a surge in the number of ratings-based regulations worldwide and boosted the credit rating business. In the United States, securities references to NRSROs increased tenfold between 1980 and $2000 .{ }^{75}$ Reliance on credit ratings intensified with the Basel II Accord, which was reached in 2004 and implemented in the following years. ${ }^{76}$ The Basel II Accord was a set of rules on banking laws and regulations issued by the Basel Committee on Banking Supervision. They established that, under the so-called "standard approach," the calculation of minimum capital requirements was contingent upon the ratings assigned to the entities a bank had claims on. The higher the rating, the lower the capital requirement. For example, banks could

70. See Comptroller Unlikely to Officially Define "Speculative" Securities, Wall St. J., Apr. 29, 1936. Since then, the speculative grade category has included bonds and issuers rated in the $\mathrm{Ba} / \mathrm{BB}$ letter category and below.

71. See Banks Given More Discretion in Investments, Wall ST. J., May 23, 1936.

72. Security Regulations Opposed by Bankers, Wall St. J., June 25, 1936. Recent research on the interwar sovereign bond market partly supports the bankers' assertion. See Flandreau supra note 27, at 497.

73. The NAIC is the standard-setter for the insurance industry, and the insurance regulators of U.S. states and territories are its members. It is organized as a private, charitable, non-profit organization headquartered in Kansas City, Missouri. With its 1951 decision, the NAIC began equating the term "investment grade bonds" with bonds having ratings of BBB/Baa or better. Thomas R. Atkinson, Trends in Corporate Bond Quality 53-54 (1967).

74. Richard Cantor \& Frank Packer, The Credit Rating Industry, 19 Fed. Res. Bank N.Y. Q. Rev. 1, 6 (1994).

75. Partnoy, The Paradox of Credit Ratings, supra note 11, at 76-77.

76. Basel Committee on Banking Supervision, International Convergence of Capital Measurement and Capital Standards-A Revised Framework, BANK FOR InTERNATIONAL Settlements 1, 5 (Nov. 2005), https://www.bis.org/publ/bcbs118.pdf [https://perma.cc/ 7B4B-4PT7]. 
apply a twenty percent risk weight to claims on corporate issuers rated between AAA and AA-. The required risk weight rose to fifty percent for corporate debt rated in the A+/A- categories, and so on. The extensive use of credit ratings by regulators is part of a larger trend of "governance by indicators." 77 Limited literature considers ratings an instrument of (private) global governance. ${ }^{78}$

At this stage, the concept of NRSRO and liability exemptions for CRAs require further analysis. Delegated monitoring started with the incorporation of references to ratings into regulatory rules. From the 1970s onward, the NRSRO designation magnified this trend. The SEC came up with the concept of NRSRO in 1975 to designate the CRAs, whose ratings could be used for regulatory purposes. ${ }^{79}$ The designation as NRSRO has been important since then because it has been a de facto prerequisite for the market to deem a CRA to be reliable. ${ }^{80}$ The NRSRO label gave select CRAs (i.e., Fitch, Moody's, and S\&P) greater market power by establishing barriers to entry and led to increased reliance on credit ratings in regulations. More insidiously, the creation of the NRSRO designation contributed to inflate the ratings of U.S. corporate issuers in the second half of the 1970s. Because CRAs had a guaranteed client base, they searched for new clients and inflated their ratings by approximately one full rating category. ${ }^{81}$

The regulatory reliance on NRSRO ratings gave CRAs an entrenched role in the governance of U.S. financial markets, ${ }^{82}$ at least until the enactment of the Dodd-Frank Act in 2010. The SEC initially abstained from defining the term "NRSRO," but in 2005, it clarified that it considered the following factors in this assessment: the CRA's organizational structure; its financial resources; the size and the quality of its staff; its independence from the companies it rated; its rating procedures; and the existence of internal procedures to prevent the misuse of nonpublic infor-

77. See Kevin E. Davis et al., Indicators as a Technology of Global Governance, $46 \mathrm{~L}$. \& Soc'y Rev. 71, 80-83 (2012) (briefly discussing credit rating agencies); Mauro Bussani, Credit Rating Agencies' Accountability: Short Notes on a Global Issue, 10 Glob. JuRIST 1, 2 (2010); Harry McVea, Credit Rating Agencies, the Subprime Mortgage Debacle and Global Governance: The EU Strikes Back, 59 InT'L \& CoMP. L.Q. 701, 703-04 (2010); EyAL Benvenisti, The Law of Global Governance 92 (2014).

78. See A. Claire Cutler et al., Private Authority and International AfFAIRs 10 (A.C. Cutler, Virginia Haufler, \& Tony Porter eds., 1999); see also ANDreas Kruck, Private Ratings, Public Regulations: Credit Rating Agencies and Global Financial Governance (2011); Bruce G. Carruthers, Credit Ratings and Global Economic Governance: Non Price Valuation in Financial Markets, in Contractual Knowledge: One Hundred Years of Legal Experimentation in Global Markets (Grégoire Mallard and Jérôme Sgard eds., 2016).

79. Considering the growing reliance on credit ratings, the designation NRSRO had strategic and financial value for CRAs. See Claire A. Hill, Regulating the Rating Agencies, 82 WASH. U. L.Q. 43, 55 (2004).

80. Since 2006, the SEC has also exercised extensive oversight over NRSROs.

81. Patrick Behr et al., Did Government Regulations Lead to Inflated Credit Ratings?, 64 Mgmt. Sci. 1034, 1035 (2018).

82. When ratings became increasingly common in other countries from the 1980 s onwards, they often imported U.S.-style regulatory reliance on ratings as well. 
mation and the compliance with these procedures. ${ }^{83}$ Specifically, NRSRO means a credit rating agency that:

(A) issues credit ratings certified by qualified institutional buyers, in accordance with section 78o-7(a)(1)(B)(ix) of this title, with respect to:

(i) financial institutions, brokers, or dealers;

(ii) insurance companies;

(iii) corporate issuers;

(iv) issuers of asset-backed securities (as that term is defined in section 1101(c) of part 229 of title 17, Code of Federal Regulations, as in effect on September 29, 2006);

(v) issuers of government securities, municipal securities, or securities issued by a foreign government; or

(vi) a combination of one or more of the categories of obligors described in any of clauses (i) through (v); and

(B) is registered under section 780-7 of this title. ${ }^{84}$

In 1975, the SEC granted NRSRO status to only three CRAs: Fitch, Moody's, and S\&P - the same three CRAs that continue to dominate the market for ratings. Only four CRAs obtained membership of this "exclusive club" between 1975 and 1991: Duff \& Phelps in 1982, Mac Carthy, Crisanti \& Maffei in 1983, IBCA in 1990, and Thomson BankWatch in 1991. Yet, the "big three" CRAs acquired each of these four CRAs in the 1990s. ${ }^{85}$ Thus, Fitch, Moody's, and S\&P were again the only NRSROs in 2000. Dominion Bond Rating Service (DBRS) obtained the NRSRO designation in 2003, as did A.M. Best in 2005. ${ }^{86}$

Following the Credit Rating Agency Reform Act of 2006, ${ }^{87}$ the number of NRSROs increased further. At the end of 2017, there were ten NRSROs: A.M. Best, DBRS, Egan-Jones, Fitch, HR Ratings de México, Japan Credit Rating Agency, Kroll Bond Rating Agency, Moody's, Morningstar, and S\&P. ${ }^{88}$ However, the big three have continued to dominate the market. Since the Credit Rating Agency Reform Act of 2006 came into force, the SEC has exercised regulatory oversight over these NRSROs.

83. Definition of Nationally Recognized Statistical Rating Organization, Exchange Act Release No. 33-8570, 70 Fed. Reg. 21,306 (proposed Apr. 25, 2005) (to be codified at 17 C.F.R. pt. 240).

84. 15 U.S.C. $\$ 78 c(a)(62)$ (2012). The Credit Rating Agency Reform Act of 2006 inserted this definition.

85. GAILlard, supra note 31 , at 96 .

86. Id.

87. The objective of the Credit Rating Agency Reform Act of 2006 was to "improve rating quality for the protection of investors and in the public interest by fostering accountability, transparency, and competition in the credit rating industry." Credit Rating Agency Reform Act of 2006, Pub. L. No. 109-291, 120 Stat. 1327 (2006) (codified as amended at 15 U.S.C. § 78o-7 (2012)).

88. SEC, supra note 34 , at 2 . 
In the late 1970s, in order to permit the disclosure of ratings in documents filed with the SEC, the Commission contemplated whether NRSROs should be required to provide consent under $\$ 7$ of the Securities Act of 1933 , thereby subjecting them to liability under $\S 11 .{ }^{89}$ NRSROs were not prepared to provide such consent if they were named in registration statements. In 1982, this refusal by the CRAs prompted the SEC to adopt Rule 436(g). Responding to concerns of the NRSROs, the new rule modified who was to be considered part of the registration statement prepared or certified by a person falling within the ambit of $\S 7$ and $\S 11$ of the Securities Act. It established that a security rating that an NRSRO assigned to a debt security was not part of the statement.

The SEC justified Rule 436(g) by reference to the existing liability of CRAs under the antifraud provisions of the federal securities laws and regulation by the Commission under the Investment Advisers Act of 1940. ${ }^{90}$ However, the Credit Rating Agency Reform Act of 2006 amended the Investment Advisers Act of 1940 to exclude NRSROs from the category of "investment adviser" to which they belonged so far. ${ }^{91}$

\section{Greater Supervision of Rating Agencies and Removal of Statutory References to Ratings}

In 2008 and 2009, the SEC identified flaws in CRAs' models and practices that had produced inaccurate SF ratings, which contributed significantly to the U.S. subprime crisis. $^{92}$ In 2010, the Permanent Subcommittee on Investigations (PSI) of the U.S. Senate released a long memorandum that explained how and why CRAs had failed in their role as financial market gatekeepers. ${ }^{93}$

The incriminating evidence was impressive. From 2004 to 2007, Moody's and S\&P neglected credit risks related to mortgage fraud and the housing price bubble. They also used inaccurate models to rate RMBS and CDOs. Once they realized their mistakes in 2006, they revised their models, but failed to use them to re-evaluate existing RMBS and $\mathrm{CDO}$, delaying thousands of downgrades. Consequently, when the sub-

89. Adoption of Integrated Disclosure System, Exchange Act Release No. 18,524, 1982 WL 90376 (Mar. 19, 1982). A security may be registered with the SEC by filing a registration statement. Section 7 of the Securities Act of 1933 originally established that "if any accountant, engineer, or appraiser, or any person whose profession gives authority to a statement made by him, is named as having prepared or certified any part of the registration statement, or is named as having prepared or certified a report or valuation for use in connection with the registration statement, the written consent of such person shall be filed with the registration statement." Securities Act of 1933, Pub. L. No. 73-22, 48 Stat. 74 (1933) (codified as amended at 15 U.S.C. $\$ \S 77 a-77$ aa (2012)).

90. Concept Release on Possible Rescission of Rule 436(g) Under the Securities Act of 1933, Exchange Act Release No. 33-9071, 96 SEC Docket 2719 (Oct. 7, 2009).

91. The Investment Advisers Act of 1940 defines investment adviser as any person or group that makes investment recommendations or conducts securities analysis in return for a fee, whether through direct management of client assets or via written publications. Investment Advisers Act of $1940 \S 202,15$ U.S.C. § 80b-2(a)(11)(F) (2012).

92. SEC, Summary Report, supra note 2; SEC, The SEC's Role, supra note 2.

93. Hearing, supra note 2. 
prime crisis amplified in July 2007, Moody's and S\&P announced massive downgrades that shocked financial markets. They also inflated their credit ratings to preserve their market shares, particularly in the SF area. ${ }^{94}$ The two main CRAs did not have sufficient resources and analysts to assign accurate ratings. ${ }^{95}$

The SEC and PSI findings were a milestone in the enactment of Title IX, Subtitle C (Improvements to the Regulation of Credit Rating Agencies) of the Dodd-Frank Act of July 2010. ${ }^{96}$ A first set of Dodd-Frank provisions focuses on credit rating methodologies. It requires that NRSROs develop internal control structure, ${ }^{97}$ use qualitative and quantitative data and models, consistently apply methodologies across ratings, ${ }^{98}$ and ensure that CRAs assess default probabilities. ${ }^{99}$ NRSROs must enhance transparency by publishing the evolutions of all ratings that facilitate comparisons across issuers, sectors, NRSROs, and time. ${ }^{100}$

In addition, Congress established the Office of Credit Ratings and gave it broad discretion in rulemaking and oversight to ensure that ratings are not "unduly influenced by conflict of interest." 101 Other provisions aimed at preventing NRSRO employees from corrupting rating processes. ${ }^{102}$ Prior to the Dodd-Frank provisions, CRAs had no legal or regulatory obligation to fight conflicts of interest. Moreover, Congress nullified Rule 436 $(\mathrm{g})^{103}$ and amended the Securities Exchange Act of 1934 to hold CRAs accountable for their statements in the same manner and to the same extent as public accounting firms under securities law. ${ }^{104}$ Lastly, Congress removed all references to credit ratings from federal regulations ${ }^{105}$ and required federal agencies to establish new uniform standards of creditworthiness. ${ }^{106}$ Cutting overreliance on credit ratings is complicated by the difficulty of finding robust substitutes.

The SEC issued various amendments to implement $\S 939 \mathrm{~A}$ of the Dodd-Frank Act. For instance, the SEC amended Forms N-1A, N-2, and

94. Gaillard \& Harrington, supra note 10, at 39.

95. Hearing, supra note 2, at 24-25. These findings are in line with Efraim Benmelech and Jennifer Dlugosz. See Benmelech \& Dlugosz, supra note 9.

96. For an overview of the Dodd-Frank Act and its capacity to prevent future financial crises, see Charles W. Murdock, The Dodd-Frank Wall Street Reform and Consumer Protection Act: What Caused the Financial Crisis and Will Dodd-Frank Prevent Future Crises?, 64 SMU L. Rev. 1243 (2011).

97. See Dodd-Frank, Pub. L. No. 111-203, § 932(a)(3), 124 Stat 1376 (2010) (codified as amended in sections 12 and 15 U.S.C.).

98. Id. § 932(r) (Credit Ratings Methodologies).

99. Id. § 938 (Universal Ratings Symbols).

100. Id. § 932(q) (Transparency of Ratings Performance).

101. Id. § 932(p)(1) (Regulation of Nationally Recognized Statistical Rating Organizations-Establishment of Office of Credit Ratings).

102. Id. § 932(a)(3) (Separation of Ratings from Sales and Marketing); Id. § 932(a)(4) (Look-Back Requirement); id. § 932(a)(5) (Report to Commission on Certain Employment Transitions).

103. Id. § 939G (Effect of Rule 436(g)).

104. Id. $\S 933$ (State of Mind in Private Actions).

105. Id. § 939 (Removal of Statutory References to Credit Ratings).

106. Id. $\S 939$ A (Review of Reliance on Ratings). 
N-3 as follows: 107

To no longer require the use of NRSRO credit ratings by funds that choose to use credit quality categorizations in the required table, chart, or graph of portfolio holdings. Accordingly, funds that choose to show credit quality categorizations in the required table, chart, or graph may use alternative categorizations that are not based on NRSRO credit ratings. . . . Funds will also be required to describe how the credit quality of the holdings was determined, and if credit ratings are used, a description of how they were identified and selected. ${ }^{108}$

The SEC also modified the broker-dealer net capital rule (Rule 15c3-1) as follows:

When a broker-dealer applies haircuts for commercial paper, nonconvertible debt, and preferred stock that have a ready market for purposes of its net capital computation, it will have the option of: (1) using the firm's own written policies and procedures to determine whether the security has only a minimal amount credit risk and, if so, applying the appropriate lower haircut if it meets the other conditions prescribed in Rule 15c3-1; or (2) applying the greater deduction applicable to the position, such as the $15 \%$ haircut under the catchall provision in paragraph (c)(2)(vi)(J) of Rule 15c3-1. Commercial paper, nonconvertible debt, and preferred stock without a ready market would continue to be subject to a $100 \%$ haircut. ${ }^{109}$

The SEC amendments to Forms N-1A, N-2, and N-3 and to Rule 15c3-1 reduce mechanistical reliance on CRA ratings, as advocated by the Financial Stability Board (FSB). ${ }^{110}$ Though they encourage investors to develop their own capacity for credit risk assessment and due diligence, the two SEC amendments do not prevent them from using credit ratings.

The removal of regulatory references to credit ratings in 2010 ended a long tradition among U.S. legislators and regulators. ${ }^{111}$ The incorporation of credit ratings into regulatory rules had been a standard feature of the U.S. regulatory landscape since the 1930s. In addition, as a result of the financial globalization of the 1980s and 1990s, Moody's and S\&P's became de facto regulators, whose opinions and decisions sparked fear

107. Forms N-1A, N-2, and N-3 contain the requirements for shareholder reports of mutual funds, closed-end funds, and certain insurance company separate accounts that offer variable annuities.

108. Removal of Certain References to Credit Ratings Under the Investment Company Act, Exchange Act Release No. 9506, 2013 WL 11309619, at *19-20 (Dec. 27, 2013).

109. Removal of Certain References to Credit Ratings Under the Securities Exchange Act of 1934, Exchange Act Release No. 34-71194, 107 SEC Docket 5717, at *14 (Dec. 27, 2013).

110. See Financial Stability Board, Principles for Reducing Reliance on CRA RAtings (Oct. 27, 2010), http://www.fsb.org/wp-content/uploads/r_101027.pdf [https://perma.cc/7PM6-8654]. The FSB is an international body that makes recommendations to enhance the global financial system.

111. This trend to no longer rely on ratings for regulatory purposes extends to other jurisdictions. See, e.g., Council Regulation (EU) 462/2013, 2013 O.J. (L 146) 1. 
among policymakers and in financial markets. ${ }^{112}$ One reason why ratings became so entrenched in the regulatory and rule-making process may be that the very name "credit rating agency" gave them a regulatory appearance, in the eyes of Congress, the SEC, and the investing public. Given that ratings appeared to be quasi-regulatory, their incorporation into regulatory rules seemed unproblematic for a long time.

We now turn to examining how litigation against mercantile agencies and CRAs has evolved since the nineteenth century.

\section{QUASI-IMMUNITY FOR CREDIT RATING AGENCIES}

This section considers the traditional position of CRAs and their predecessor, mercantile agencies, in litigation in U.S. courts. There are two main potential plaintiffs against CRAs: investors that use ratings in their decisions, and issuers adversely affected by (changes to) ratings. We first consider defamation claims against mercantile agencies in the nineteenth century. We then analyze how U.S. courts came to regard credit ratings as constitutionally protected free speech under the First Amendment to the U.S. Constitution. The effect was that free speech became an almost impenetrable shield. CRAs enjoyed almost complete immunity in U.S. courts in suits for liability based on erroneous ratings. The final sub-section addresses securities litigation against CRAs.

CRAs enjoyed "quasi-immunity" as long as they assigned their ratings in the interest of investors, and the courts considered them speech under the First Amendment. However, once CRAs shifted their business model, charged issuers for ratings, and assigned their ratings in the interest of issuers (i.e., the investment banks that issued SF products, rather than investors), their ratings and reports became commercial speech. We argue that CRAs succumbed to the Icarus Syndrome. ${ }^{113}$ Their closer relations with powerful investment banks that underwrote, issued, and traded SF products damaged their credibility and lessened their capacity to be shielded by the First Amendment from potential liability for erroneous ratings. When CRAs increasingly assigned biased and inflated ratings over the last decade, they became vulnerable to lawsuits and regulatory enforcement.

\section{A. Defamation as the Focus of Early Litigation}

Defamation was the main challenge for mercantile agencies in the nineteenth century, but not for CRAs for most of the twentieth century. In the first legal actions based on the reports of mercantile agencies in the second half of the nineteenth century, U.S. courts sought to define the

112. Recall what New York Times columnist Thomas Friedman declared in 1996: "There are two superpowers in the world today in my opinion. There's the United States and there's Moody's Bond Rating Service. The United States can destroy you by dropping bombs, and Moody's can destroy you by downgrading your bonds. And believe me, it's not clear sometimes who's more powerful." Partnoy, supra note 40, at 620.

113. Gaillard, supra note 30 , at $184-85$. 
legal responsibilities of the agencies and of the businesspersons who used them.

The key early case of Tappan v. Beardsley against the Mercantile Agency resulted in $\$ 10,000$ in damages for libel, a significant liability. ${ }^{114}$ Yet, then, a major change in the legal definition of "privileged communication" was set forth in Ormsby v. Douglass, ${ }^{115}$ challenging Beardsley's approach to liability for libel. There, a businessperson who believed that a report was incorrect and unjust sued the Mercantile Agency. The Agency argued that the reading of a report sent to a subscriber constituted a privileged communication, and therefore was not subject to the charge of slander. ${ }^{116}$ However, the court disagreed.

State v. Morgan further considered the status of mercantile agencies. ${ }^{117}$ Dun sued on behalf of Morgan, one of its agents. South Dakota had fined Morgan for failing to register in the state. The Supreme Court held that mercantile agencies fell under both federal and state control, and could be regulated by both. It rejected Dun's argument that this amounted to an interference with interstate commerce.

Another early libel case against a mercantile agency found its way to the Privy Council in England. In Macintosh v. Dun, ${ }^{118}$ Macintosh sued Dun based on a report indicating that Macintosh was an ill-reputed trader. Having originated in the High Court of Australia, the issue on which the Privy Council's decision turned was whether the communication between Dun and its client was privileged. If so, the liability in libel would be reduced. While the trial judge had found in favor of the plaintiff, the high court entered judgment for the defendant. The Privy Council concluded that the information was not privileged, and Macintosh's action in libel was successful. The Privy Council reasoned that Dun was a commercial enterprise.

The occasion was privileged if the communication injurious to the plaintiffs' character was made in the general interest of society and from a sense of duty; not so, if it was made from motives of self-interest by those who, for the convenience of a class, trade for profit in the characters of other persons, and who offer for sale information which, however cautiously and discreetly sought, may have been improperly obtained. "However convenient it may be to a trader to know all the secrets of his neighbor's position, his 'standing,' his 'responsibility,' and whatever else may be comprehended under the expression 'et cetera,' yet, even so, accuracy of information may be bought too dearly-at least for the good of

114. Tappan v. Beardsley, 77 U.S. 427, 433 (1870). According to MeasuringWorth, this amounts to $\$ 23$ million in today's money. On Tappan and the Mercantile Agency, see supra Part II.B.1.

115. Ormsby v. Douglass, 37 N.Y. 477 (1868).

116. Id. at 479-80; see also Joseph Errant, The Law Relating to Mercantile Agencies, T. \& J. W. Johnson \& Co. 8 (1889). Cf. Minter v. Bradstreet Co., 73 S.W. 668, 668 (Mo. 1903) (another libel case against Bradstreet before it became Dun \& Bradstreet).

117. State v. Morgan, 48 N.W. 314, 315 (S.D. 1891).

118. Macintosh v. Dun [1908] AC 390 (P.C. 1908) (Austl.). 
society in general."119

U.S. courts later quoted this decision, with one trial judge stating that "the company that goes into the business of selling news or reports about others should assume the responsibility for its acts, and must be sure that it is peddling the truth." 120 Academic criticism of this decision followed in 1914. ${ }^{121}$ Dun faced at least ninety-five libel lawsuits between 1880 and 1900 , indicating that mercantile agencies operating during this period faced considerable litigation. ${ }^{122}$

This contrasts with the few lawsuits against CRAs in the first half of the twentieth century. We searched reported lawsuits involving one of today's major three CRAs, known by their current (Fitch, Moody's, S\&P) or former names (Poor's and Standard Statistics). Most early cases did not involve claims based on the liability of the rating agency for its rating. Instead, the early cases involving a rating firm showed that the courts relied on credit ratings to make their decisions. ${ }^{123}$ For instance, in an early decision involving Poor's, Henry W. Poor \& Co. was sued in an action to rescind a contract "of [a] sale to plaintiff [Lawson] upon the ground of false representation made by the defendant Henry W. Poor ... which representations were the inducing cause to plaintiff of such purchase." 124

Very early, U.S. courts started to give high credence to ratings as a reliable source of information. For instance, In re Bartol concerned a challenge of a trustee's purchase of an electric railway bond, and referred to Poor's 1890 Manual in the following terms: "[i]t must be conceded under the evidence, that the trustees used all the care that a person of ordinary care and prudence would use in determining upon an investment of his personal funds." 125 In re Detre's Estate confirmed that a trust properly purchased certain bonds in reliance on a Moody's rating. "In Moody's Manual for 1914, these . . . bonds are rated: Security, very high;

119. Id. Marc Flandreau and Gabriel Geisler Mesevage's historical research identified these early cases. See Marc Flandreau \& Gabriel Geisler Mesevage, The Untold History of Transparency: Mercantile Agencies, the Law, and the Lawyers (1851-1916), 15 ENTER. \& Soc'y 213, 215 (2014) (arguing that rating agencies, as we know them today, developed out of the early mercantile agencies not due to cultural demand for their services, but rather as a result of business interest, in spite of the law).

120. Pac. Packing Co. v. Bradstreet Co., 139 P. 1007, 1010 (Idaho 1914).

121. See Jeremiah Smith, Conditional Privilege for Mercantile Agencies.-Macintosh v. Dun, 14 Colum. L. Rev. 187, 192 (1914) [hereinafter Dun I]; Jeremiah Smith, Conditional Privilege for Mercantile Agencies.-Macintosh v. Dun II, 14 Colum. L. Rev. 296, 310 (1914) [hereinafter Dun II].

122. Flandreau \& Mesevage, supra note 119, at 239.

123. For a survey of these early cases against CRAs, see Flandreau \& Sławatyniec, Financial History Review 257 (2013). Their appendix shows that most cases referring to rating agencies during the period 1900-1940 were concerned with the various forms of reliance on their ratings, rather than with agency liability for ratings. Their data suggests that litigation against CRAs during this period was extremely limited, in line with the very few instances of libel suits against CRAs that we found.

124. Willets v. Poor, 126 N.Y.S. 926, 927 (N.Y. App. Div. 1910). Cf. Poor's Publ'g Co. v. Banca Marmorosch Blank \& Co., 193 N.Y.S. 950, 950 (N.Y. App. Div. 1922).

125. In re Bartol, 38 A. 527, 530 (Pa. 1897). 
Salability, good; net rating, A."126

CRAs were not a major target of litigation after the Great Depression, contrary to what one might expect, given their poor track record of performance in the interwar period, especially when rating U.S. states and municipalities. ${ }^{127}$ There were a few cases, but for the most part they did not concern CRA liability to investors or regulators, and accordingly, these decisions do not set a precedent for the contemporary liability of CRAs. For instance, Fitch was sued for copyright infringement in 1923.128 Early lawsuits in which Moody's was a party included Moody's Investors Service v. Taylor in 1938. ${ }^{129}$ A significant decision against Dun \& Bradstreet came in 1936,130 and another came against Standard Statistics in $1942 .{ }^{131}$

\section{B. Free Speech Protection as the Prevailing Defense for CRedit Rating Agencies ${ }^{132}$}

For most of the post-World War II period, U.S. courts were unanimous on the qualification of ratings as free speech. They did not address the free speech vs. commercial speech dilemma until the 1980 s. $^{133}$ In the first two decades of the twenty-first century, the First Amendment no longer provides complete immunity to CRAs in respect of their ratings.

U.S. courts have traditionally considered ratings as speech protected by the freedom of expression under the First Amendment, as the case law below demonstrates. Yet, as this section shows, recent U.S. cases have challenged the status of ratings as protected speech. ${ }^{134}$ In addition, certain non-U.S. jurisdictions have developed a duty of care owed by CRAs to investors, despite the difficulties associated with identifying specific civil-law liability norms in relation to erroneous or negligent ratings. ${ }^{135}$

126. In re Detre's Estate, 117 A. 54, 56 (Pa. 1922). The court also relied on a Moody's rating in In re Winburn's Will, 249 N.Y.S. 758, 762 (Sur. Ct. 1931).

127. See George H. Hempel, The Postwar Quality of State and Local Debt 108-13 (Colum. Univ. Press 1971).

128. See Inv. Serv. Co. v. Fitch Pub. Co., 291 F. 1010, 1011 (7th Cir. 1923).

129. See generally Moody's Inv'rs Serv. v. Taylor, 5 N.Y.S.2d 765 (N.Y. App. Div.1938).

130. See generally Century Bias Binding Co. v. Dun \& Bradstreet, 292 N.Y.S. 950 (N.Y. App. Div. 1936); Dun \& Bradstreet, Inc. v. City of New York, 11 N.E.2d 728, 737 (N.Y. 1937).

131. Standard Statistics Co. v. Davis, 45 N.E.2d 1005, 1006 (Ill. App. Ct. 1936).

132. See Aldo Caliari, Assessing Global Regulatory Impacts of the U.S. Subprime Mortgage Meltdown: International Banking Supervision and the Regulation of Credit Rating Agencies, 19 Transnational L. \& Contemp. Probs. 145 (2010); McVea, supra note 77; Lawrence J. White, Credit Rating Agencies and the Financial Crisis: Less Regulation of CRAs is a Better Response, 25 J. InT'L BANking L. \& Reg. 1 (2010).

133. Cf. Dun \& Bradstreet, Inc. v. Greenmoss Builders, 472 U.S. 749, 783 (1985).

134. Notably, this is illustrated by the Abu Dhabi litigation. See Abu Dhabi Comm. Bank v. Morgan Stanley \& Co., 651 F. Supp. 2d 155, 175-76 (S.D.N.Y. 2009).

135. Comparative analysis of the liability of rating agency suggests that in most jurisdictions it is difficult to identify such norms. See Uwe Blaurock, Control and Responsibility of Credit Rating Agencies, 11 Electronic J. Comp. L. 1, 20 (2007). Due to the nature of the assessments of risk made by rating agencies, the end product, a prediction of the future, is difficult to prove correct or incorrect. This is the first problem with determining liability, but it does not preclude the possibility of holding a rating agency liable, since it may be 
Most importantly, in November 2012, the Federal Court of Australia (FCA) was the first in a common law jurisdiction to find that a rating agency owed a duty of care to potential investors. ${ }^{136}$ The case arose out of the sale ratings of complex collateralized debt obligations purchased by Australian municipalities. The Australian court found that a reasonably competent rating agency could not have rated the Rembrandt 2006-3 CPDO AAA under the circumstances at issue, and that Standard \& Poor's AAA rating of the Rembrandt 2006-2 and 2006-3 CPDO notes was "misleading and deceptive." This was because the ratings involved the publication of information or statements false in material particulars and involved negligent misrepresentations to the class of potential investors in Australia, as the AAA rating conveyed that in S\&P's opinion, the capacity of the notes to meet all financial obligations was "extremely strong" and a representation that S\&P's opinion was based on reasonable grounds and as the result of an exercise of reasonable care. Neither of these representations were true, and S\&P knew this at the time the representations were made. Ultimately, the Australian court found S\&P to be jointly liable with ABN Amro and LGFS. ${ }^{137}$

The liability of rating agencies to issuers wishing to bring claims for damages arising from, for example, low evaluations, unwarranted downgrades, or a refusal to upgrade, may be sought by an issuer in a tort claim, especially when the issuer did not request the rating and had not entered into a contract with the rating agency. ${ }^{138} \mathrm{~A}$ tort claim of this type may be limited by constitutional protections of free speech, which courts in many jurisdictions have applied to published ratings, with a few possible exceptions such as Canada. ${ }^{139}$

In the United States, the First Amendment to the Constitution states that "Congress shall make no law ... abridging the freedom of speech, or

possible to identify wrongful errors in the analysis, data sources, or methodologies employed by the agency. The first key distinction to be drawn is between liability based on a wrongful product (difficult to show as anything but a subjective opinion) and liability founded on wrongful means of obtaining the product (easier to show objectively justifiable errors). However, proving that the means employed by a rating agency were wrongful may be highly problematic due to lack of access to evidence or the highly contested nature of the algorithms and other means of analysis used, and because these means are often not transparently disclosed. See generally Frank Pasquale, The Black Box Society: The Secret Algorithms that Control Money and Information (Harv. U. Press 2015) (providing an exhaustive analysis on how economic and financial strategies rely on hidden algorithms).

136. See Bathurst Reg'l Council v Local Gov't Fin Servs Pty Ltd (No. 5) [2012] FCA 1200, II 2263 (Austl).

137. $I d$.

138. In 1996-1999, the Department of Justice examined whether Moody's used the threat of unsolicited ratings to grab market shares. No anti-competitive practices were found. See Kenneth N. Gilpin, Justice Dept. Inquiry on Moody's Is Over, With No Charges Filed, N.Y. Times (Mar. 13, 1999), https://www.nytimes.com/1999/03/13/business/justicedept-inquiry-on-moody-s-is-over-with-no-charges-filed.html. Traditionally, ratings were only on request, but unsolicited ratings have become more common. See Davis, supra note 77 , at 81 (referring to rating agencies as an example of the "symbiotic relationship between those who measure and those who are measured").

139. Blaurock, supra note 135, at 20. 
of the press." ${ }^{140}$ Historically, U.S. courts have considered ratings as opinions on matters of public concern, and therefore as protected speech under the First Amendment. The actual malice exception, which provides an exception to the First Amendment protection, has been of little assistance to plaintiffs in litigation against rating agencies. ${ }^{141}$

The U.S. Supreme Court first used the standard in relation to credit agencies in New York Times Co. v. Sullivan, ${ }^{142}$ which concerned an advertisement in the New York Times that solicited funds to defend Martin Luther King, Jr. against an Alabama perjury indictment. The Montgomery Public Safety Commissioner (Sullivan) alleged that the advertisement included inaccurate information in relation to police action against civil rights protesters, and that this amounted to a defamatory act against him, although the advertisement did not name Sullivan himself. ${ }^{143}$ The Court held that the First Amendment "prohibits a public official from recovering damages for a defamatory falsehood relating to his official conduct unless he proves that the statement was made with 'actual malice' - that is, with knowledge that it was false or with reckless disregard of whether it was false or not."144

Similarly, the Sixth Circuit in Compuware v. Moody's Investors Service $^{145}$ considered ratings as opinions on matters of public concern. Moody's rating of Compuware, a publicly held corporation, was subject to the standard of actual malice. ${ }^{146}$ The court found that a

Moody's credit rating is a predictive opinion, dependent on a subjective and discretionary weighing of complex factors. We find no basis upon which we could conclude that the credit rating itself communicates any probably false factual connotation. Even if we could draw any fact-based inferences from this rating, such inferences could not be proven false because of the inherently subjective nature of Moody's ratings calculation. ${ }^{147}$

This decision represents the traditional position in relation to First Amendment protection of ratings. ${ }^{148}$ According to an established line of cases, credit ratings fall within the scope of First Amendment protection. Consequently, the orthodox position is that CRAs were not liable to investors even when there was a contract between the plaintiff and the defendant. ${ }^{149}$ In Jefferson County School District v. Moody's Investor's

140. U.S. Const. amend. I.

141. In 2011, Fait v. Regions Fin. Corp., 655 F.3d 105, 110-11 (2d Cir. 2011), created a further hurdle. The Second Circuit established that investors suing in federal courts need to show that agencies did not believe their own ratings at the time they issued them.

142. 376 U.S. 254 (1964).

143. Id. at $256-57$.

144. Id. at 279-80.

145. Compuware v. Moody's Inv. Servs., Inc., 499 F.3d 520 (6th Cir. 2007).

146. Id. at 525 .

147. Id. at 529 .

148. Cf. Cty. of Orange v. McGraw Hill Cos., 245 B.R. 151, 155 (C.D. Cal. 1999).

149. For example, Orange County sued the parent company of S\&P following the bankruptcy of Orange County. See Mark Baldassare, When Government Fails: The Orange County Bankruptcy 1-33 (U. of Cal. Press 1998). 
Services, Inc., the Tenth Circuit upheld a lower court in granting First Amendment protection to Moody's. ${ }^{150}$ The case concerned a contractual claim against Moody's by a school district for intentional interference with contractual obligations after Moody's published a "negative outlook" on its bonds. In In re Enron Corp. Securities, Derivative \& "ER$I S A$ " Litigation, the District Court for the Southern District of Texas granted First Amendment protection and dismissed negligent misrepresentation claims. ${ }^{151}$ In Fait v. Regions Financial Corp., the Second Circuit required investors suing in federal courts to show that agencies did not believe their own ratings at the time they issued them - a very high threshold. ${ }^{152}$

Importantly, this First Amendment line of cases has limited the SEC's ability to regulate CRAs. Freedom of speech has acted as a shield to meaningful regulation of CRAs by the main federal securities regulator, even if the SEC had wanted to subject CRAs to strong regulation and oversight. ${ }^{153}$ CRAs have argued that they are like members of the financial press, their ratings being akin to a short editorial. ${ }^{154}$ In some cases, the courts agreed. For example, in First Equity Corp. of Florida v. Standard \& Poor's, S\&P was effectively treated as part of the media industry ${ }^{155}$ First Equity had brought a claim for negligent misstatement against S\&P after it had suffered a loss of $\$ 200,000$ because it relied on recommendations in the CRA's publications. In other cases, however, CRAs were not able to avail themselves of the protections under New York's press shield laws concerning discovery, on the basis that the CRA had not shown that it gathered information pursuant to a news function. Rather, it acted more for the needs of its clients. ${ }^{156}$

\section{Litigation Under Securities Law}

Investors and regulators have also brought some claims against CRAs under $\S 11$ of the Securities Act of 1933 . Section 11 provides for liability

150. Jefferson Cty. Sch. Dist. No. R-1 v. Moody's Inv. Servs., Inc., 988 F. Supp. 1341, 1348 (D. Colo. 1997), aff'd, 175 F.d 848 (10th Cir. 1999). Cf. In re Enron Corp. Sec., Derivative \& "ERISA" Litig., 511 F. Supp. 2d 742, 827 (S.D. Tex. 2005).

151. In re Enron Corp. Sec., Derivative \& "ERISA" Litig., 511 F. Supp. 2d at 827.

152. Fait v. Regions Fin. Corp., 655 F.3d 105, 113 (2d Cir. 2011). For further commentary on the implications of the case, see Javier Bleichmar \& Cynthia Hanawalt, The Evolving Legacy Of 'Fait v. Regions Financial', N.Y. L. J. (May 3, 2013, 12:00 AM), https://www .law.com/newyorklawjournal/almID/1202598476986/[http://perma.cc/CLS9-VAWQ].

153. See Lowe v. SEC, 472 U.S. 181, 228 (1985). For further comment, see Francis A. Bottini, Jr., Comment, An Examination of the Current Status of Rating Agencies and Proposals for Limited Oversight of Such Agencies, 30 SAN Diego L. Rev. 579, 615-20 (1993).

154. See Gregory Husisian, What Standard of Care Should Govern the World's Shortest Editorials?: An Analysis of Bond Rating Agency Liability, 75 Cornell L. Rev. 411 (1990); Jonathan W. Heggen, Not Always the World's Shortest Editorial: Why Credit-RatingAgency Speech Is Sometimes Professional Speech, 96 Iowa L. Rev. 1745, 1758-59 (2011).

155. First Equity Corp. of Fla. v. Standard \& Poor's Corp., 690 F. Supp 256, 257 (S.D.N.Y. 1988), aff'd, 869 F.2d 175 (2d Cir. 1989); see also In re Pan Am Corp., 161 B.R. 577, 582 (S.D.N.Y. 1993); In re Scott Paper Co. Sec. Litig., 145 F.R.D. 366, 370 (E.D. Pa. 1992).

156. Fitch v. UBS, 330 F.3d 104, 109 (2d Cir. 2003). 
for material misstatements and omissions in public offering documents. Traditionally, these securities claims have failed because the courts did not regard CRAs as "underwriters" within the meaning of $\S 11 . .^{157}$

In Mallinckrodt Chemical Works v. Goldman, Sachs \& Co, investors relied upon a CRA's negligent misstatement regarding the terms of a securities offering. ${ }^{158}$ Mallinckrodt Chemical Works filed this action against Goldman Sachs alleging violations of $\$ 12(2)$ and $\S 17(a)$ of the Securities Act. Jurisdiction was, among others, based on $\S 22$ (a) of the Act. The District Court for the Southern District of New York refused to hold Goldman Sachs liable for its misstatement of the terms of a security offering in the CRA's regular publications. Two factors were important to the court. First, the investor was not in privity with Goldman Sachs, apart from a simple subscription agreement for the rating publications. Second, Mallinckrodt could have referred to the original prospectus for the correct description, but failed to do so.

In First Equity Corp. v. Standard \& Poor's, an investor had relied upon a rating agency's incorrectly high rating of a company's commercial paper. ${ }^{159}$ The court found the rating was not negligent, even though the company had arguably used oversimplified accounting methods and the CRA overlooked important financial information, such as company losses hundreds of millions of dollars. The court found that the subscription agreement was insufficient to establish the degree of privity of contract necessary to give rise to liability in the face of other important factors.

At the dawn of the subprime crisis of 2007-2008, S\&P, Moody's, and Fitch were in an exceptional position: they posted very high profit margins, acted as de facto regulator in capital markets, and enjoyed quasijudicial immunity. However, the transition into advisory services changed the nature of their speech. Combined with a tendency to inflate ratings in order to grab market shares, this transformation made CRAs much more vulnerable to lawsuits, especially from investors.

\section{THE EROSION OF THE FREEDOM OF SPEECH DEFENSE FOR CRAS}

This Section shows how the impenetrable shield that CRAs enjoyed in U.S. courts has eroded over the last decade. We document that once ratings no longer benefited from heightened constitutional protection for (political) free speech, CRAs faced the specter of liability. Increasingly, courts came to regard ratings as mere commercial speech that did not raise major public concerns - in contrast to the heightened constitutional

157. The position remains largely unchanged after the global financial crisis. See infra Section III.

158. Mallinckrodt Chem. Works v. Goldman, Sachs \& Co., 420 F. Supp. 231, 234 (S.D.N.Y. 1976).

159. First Equity Corp. of Fla. v. Standard \& Poor's Corp., 869 F.2d 175, 179 (2d Cir. 1989). 
protection for political free speech under the First Amendment. We examine recent litigations against CRAs to demonstrate this important shift in the approach of U.S. courts.

\section{A. Credit Ratings as a Form of Commercial Speech}

The development of the issuer-pay model ${ }^{160}$ from 1968 raised questions about whether ratings constitute commercial speech-a type of communication that, under the First Amendment, receives less robust protection. The courts have refined the definition of commercial speech under the First Amendment over the years. That said, in U.S. constitutional law, commercial speech is a flexible category that has remained open to new categories of speech. The requalification of credit ratings as mere commercial speech, rather than as free speech, represents an important shift that challenged the quasi-immunity of CRAs. The figure below shows the evolution of litigation against CRAs.

\section{Number of Cases Against CRA Per Decade ${ }^{161}$}

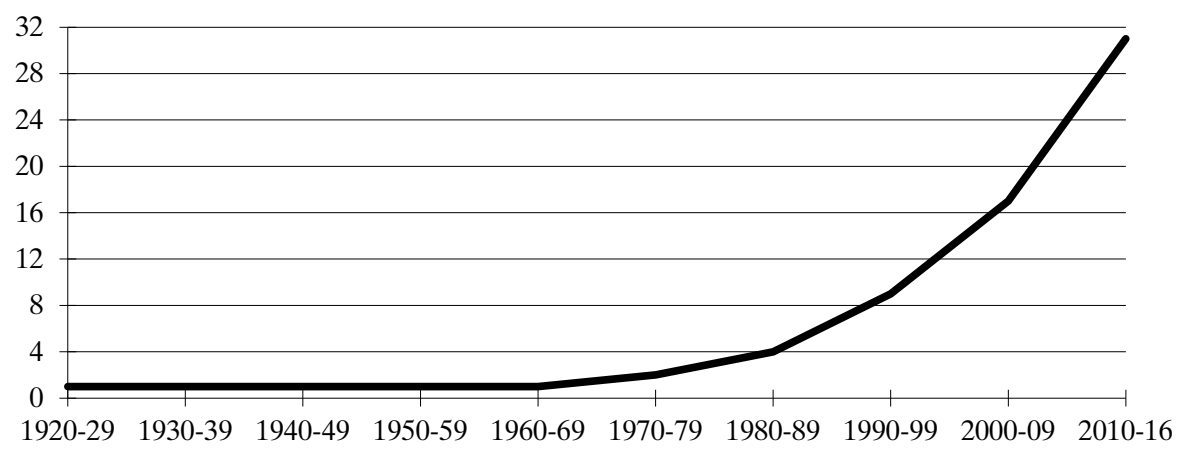

CRAs have argued that the category of "commercial speech," which is subject to lessened First Amendment protections, is limited to promotional advertising. In contrast, credit ratings are merely opinions (independent evaluations) about commercial transactions that do not themselves propose commercial transactions ${ }^{162}$ and qualify for full First Amendment protection. They are not "commercial speech."

160. See supra Section II.A.

161. This graphic is based on sixty-eight reported cases. We compiled a complete set of cases brought against CRAs in the United States. We performed searches on Westlaw and LexisNexis involving one of today's major three CRAs, known by their current (Fitch, Moody's, S\&P) or former (Poor's and Standard Statistics) names, and parents and subsidiaries. We excluded cases that do not relate to the liability based on ratings, such as employment lawsuits. Since we focus on publicly available judicial opinions, there may be some bias in case selection by LexisNesis and Westlaw. See John Armour et al., Delaware's Balancing Act, 87 Indiana L.J. 1346, 1355 (2012). Searches on PACER for cases filed suggest that selectivity is not a major concern for the last two decades, but it could be a significant concern for earlier periods.

162. Letter from Laurence H. Tribe \& Thomas C. Goldstein, Legal Consultants, Moody's, to Elizabeth M. Murphy, Sec'y, Sec. \& Exch. Comm'n 2 (Dec. 14, 2009). 
In Virginia State Board of Pharmacy, the U.S. Supreme Court defined commercial speech as speech that does nothing more than propose a transaction. The plaintiffs had brought a First Amendment challenge against a Virginia law, which prohibited the advertisement of prices for prescription drugs by pharmacists who would otherwise be guilty of "unprofessional conduct." The Court took the view that "[p]eople will perceive their own best interests if only they are well enough informed, and ... the best means to that end is to open the channels of communication rather than to close them." 163 It further held that "[a]s to the particular consumer's interest in the free flow of commercial information, that interest may be as keen, if not keener by far, than his interest in the day's most urgent political debate." 164 That the speaker's interest is purely economic is irrelevant in determining whether the speech is protected. ${ }^{165}$ The Court held that while commercial speech is protected speech under the First Amendment, the state could regulate some forms of commercial speech. It may be restricted if (1) it is justified without reference to the content of the regulated speech, (2) it serves a significant governmental interest, and (3) in doing so, it leaves ample alternative channels for communication of the information. ${ }^{166}$

In Central Hudson Gas \& Electricity Corporation, concerning a challenge to a Public Service Commission regulation that prohibited promotional advertising by electric utilities, the Supreme Court defined commercial speech as expression that relates solely to the economic interests of the speaker and its audience. ${ }^{167}$ The negative definition of commercial speech is more helpful than its positive counterpart. Accordingly, commercial speech is not speech on which money has been spent to project the speech; it is not speech in a form that is sold for profit; it is not speech that solicits money; nor is it speech on a commercial subject. ${ }^{168}$

LaSalle v. Duff \& Phelps represents an important shift in the history of lawsuits involving CRAs. ${ }^{169}$ The plaintiff, LaSalle National Bank, claimed that Duff \& Phelps failed to properly review and monitor the bonds in question, and alleged that this failure caused it material loss in reliance on the agency's AA rating. The plaintiff alleged that the rating agency acted without the necessary due diligence and had orally misrepresented the security of the bonds. Crucially, the court rejected the argument that a publisher of credit ratings is a member of the free press and thereby entitled to the same privileges. Since LaSalle had privately contracted with

163. Va. State Bd. of Pharmacy v. Va. Citizens Consumer Council, Inc., 425 U.S. 748, 770 (1976) (quoting Pittsburgh Press Co. v. Human Relations Comm'n, 413 U.S. 376, 385 (1973)).

164. Id. at 763 .

165. Id. at 762 .

166. Id. at 771 .

167. Cent. Hudson Gas \& Elec. Corp. v. Pub. Serv. Comm'n, 447 U.S. 557, 561 (1980).

168. See Alex Kozinski \& Stuart Banner, Who's Afraid of Commercial Speech?, 76 VA. L. Rev. 627, 638 (1990).

169. LaSalle Nat'l Bank v. Duff \& Phelps Credit Rating Co., 951 F. Supp. 1071, 1086 (S.D.N.Y. 1996). 
Duff \& Phelps with respect to a private placement Offering Memoranda, rather than for publication to the public, it was not entitled to the privileges of a journalist. The New York district court also rejected the CRA's attempt to rely on the "actual malice" standard, established in New York Times $v$. Sullivan. ${ }^{170}$

LaSalle sowed the seeds of the collapse of the immunity defense for CRAs. When CRAs developed ancillary businesses in the 1990s, courts were more likely to regard their ratings as commercial speech and deny CRAs full First Amendment protection for two reasons. ${ }^{171}$ First, CRAs disseminated SF products (SFP) typically to a small group of qualified institutional investors for securities offered under Rule 144A. ${ }^{172}$ Second, ratings were solely in the individual interests of CRAs and their audience.

\section{B. The "Public Concern" Condition for First Amendment Protection}

For the most part, the First Amendment has protected CRAs not because they are analogous to journalists, but instead because their ratings touch upon matters of public concern. Those who publish information to the community at large, even where paid by advertisers to do so, face no liability in libel when they speak on matters of public concern, unless they knowingly or recklessly publish false information. The crucial factor for whether ratings touch public concern is whether the ratings are available to the public at large or only to a select group of investors. Importantly, speech directed at "a specific business audience" does not qualify as a matter of public concern. In the absence of a matter of public concern, courts have tended to reject a CRA's invocation of the First Amendment. ${ }^{173}$

Whether something is a matter of public concern hinges on its content, form, and context. ${ }^{174}$ In Dun \& Bradstreet, Inc. v. Greenmoss Builders, an important precedent dating back to the 1980s, the Supreme Court considered ratings to raise "private" rather than "public" concern. ${ }^{175}$ The Supreme Court established that "a credit rating's content, form, and context

170. Id. at 1096-97.

171. For example, Moody's and S\&P developed "risk consulting" businesses through the creation of their "Rating Assessment Service" and "Ratings Evaluation Service," respectively. See New Interests, New Conflicts, ECONOMIST (Apr. 12, 2001), https://www.economist.com/finance-and-economics/2001/04/12/new-interests-new-conflicts [https://perma.cc/ L9MR-KEYP]. SEC, Report to Congress: Credit Rating Agency Independence STUdY 18 (Nov. 2013) (a recent analysis of NRSRO ancillary services).

172. See 17 C.F.R. $§ 230.144$ A (2017).

173. E.g., Genesee Cty. Emps. Ret. Sys. v. Thornburg Mortg. Sec. Tr. 2006-3, 825 F. Supp. 2d 1082, 1237 (D.N.M. 2011).

174. The leading case is Dun \& Bradstreet, Inc. v. Greenmoss Builders, 472 U.S. 749, 763 (1985). See also Connick v. Myers, 461 U.S. 138, 147-48 (1983); In re Nat'l Century Fin. Enters., Inc., 580 F. Supp. 2d 630, 639-40 (S.D. Ohio 2008); Cal. Pub. Emps. Ret. Sys. v. Moody's Invs. Serv., Inc., 172 Cal. Rptr. 3d 238, 250 (Cal. Ct. App. 2014); Jonathan S. Sack \& Kefira R. Wilderman, Civil Liability of Rating Agencies: Past Success, Future Danger?, N.Y. L. J. 4 (Sept. 15, 2010, 12:00 AM), https://www.law.com/almID/1202472017174/.

175. Dun \& Bradstreet, 472 U.S. at 763. 
... indicate[s] whether such rating is of public concern or not." 176 It concluded that First Amendment immunity did not apply because the speech was only "in the individual interest of the speaker and its specific business audience." 177 The Court distinguished credit reporting agencies from the traditional media because, unlike the traditional media, they are "in the business of selling financial information to ... subscribers who have paid substantial fees for their services." And the statements were "solely motivated by the desire for profit." 178

In Abu Dhabi Commercial Bank v. Morgan Stanley, the District Court for the Southern District of New York applied the Dun \& Bradstreet test, departing from the traditional position in relation to the First Amendment defense. ${ }^{179}$ Abu Dhabi Commercial Bank alleged negligent misrepresentation and other fraudulent behavior by Moody's and S\&P. The court rejected the CRAs' claim to First Amendment protection on the basis that they disseminated the ratings only to a select group of investors in connection with a private placement. The ratings were therefore not a matter of public concern. ${ }^{180}$ The court applied a three-part test to determine whether ratings were a matter of public concern: (1) how widely did the CRA disseminate the report; (2) the CRA's state of mind and its knowledge; and (3) the CRA's conflicts of interest in providing the rating. ${ }^{181}$

In the earlier case of In re National Century, the Southern District Court for Ohio rejected the defendant's First Amendment arguments because the ratings aimed at a "specified business audience," citing Dun \& Bradstreet, and hence did not qualify as a matter of public concern. Accordingly, the court dismissed claims based on common law fraud and $\$ 10(b)$ of the Securities Exchange Act of 1934 against the rating agencies, but upheld claims of negligent misrepresentation, and aiding and abetting fraud. ${ }^{182}$ In Kings County, Washington v. IKB Deutsche Industriebank $A G$, the District Court for the Southern District of New York upheld common law fraud claims against a rating agency for assigning allegedly false and misleading high ratings to certain structured finance products. ${ }^{183}$

In In re Fitch, the Second Circuit denied First Amendment protection to Fitch. It reasoned that a Fitch employee took "a fairly active role . . . in

176. For example, in Cal. Pub. Emps. Ret. Sys., ratings were disseminated to a select group of investors in connection with a private placement rather than to the general public. See 172 Cal. Rptr. at 639-40.

177. Dun \& Bradstreet, 472 U.S. at 753.

178. Id. at 762 .

179. Abu Dhabi Commercial Bank v. Morgan Stanley \& Co., 651 F. Supp. 2d 155, 175-76 (S.D.N.Y. 2009).

180. Id.

181. Id. at $176-80$.

182. In re Nat'l Century Fin. Enters., Inc., Inv. Litig., 580 F. Supp. 2d 630, 640 (S.D. Ohio 2008).

183. See King County v. IKB Deutsche Industriebank AG, 708 F. Supp. 2d 334, 347 (S.D.N.Y. 2010). 
commenting on proposed transactions and offering suggestions about how to model the transactions to reach the desired ratings," which demonstrated "a level of involvement with the client's transactions that is not typical of the relationship between a journalist and the activities upon which the journalist reports." 184 Fitch was a non-party to the actual case. It merely tried to quash a subpoena. Because Fitch was not behaving like a typical journalist, the court held that its CDO rating was not an issue "of public concern." Fitch could not avail itself of protection under the First Amendment, and the court accordingly dismissed its request to quash the subpoena.

Central to the common law claims brought in U.S. courts is the distinction between publicly available statements that are provided with the prime intention of serving private clients on the one hand, and statements that are aimed at the public at large on the other hand. Traditionally, the courts grant freedom of speech protection only in relation to the latter category-information intended for public consumption. Conversely, such protection does not apply where the CRA provides information to a group of private individuals, notwithstanding its availability to the public. ${ }^{185}$

In summary, the First Amendment likely offers CRAs strong protection if their ratings implicate matters of public concern and are akin to mere opinions containing no verifiable facts. In such situations, CRAs face liability for fraud only in the extraordinary case where plaintiffs can prove that CRAs did not believe that the ratings that they distributed were accurate (the actual malice standard). In contrast, where they either communicate their opinions in a professional capacity to targeted investors or do no more than propose a commercial transaction, they likely face more extensive liability for common law negligence, misrepresentation or fraud.

\section{THE GLOBAL FINANCIAL CRISIS AS A CATALYST FOR RATING AGENCIES}

Following the global financial crisis of 2008, private litigants, the U.S. federal government and various state governments, public pension funds, and others brought dozens of lawsuits against CRAs in state and federal courts against the three major CRAs for ratings issued prior to the finan-

184. In re Fitch, Inc., 330 F.3d 104, 111 (2d Cir. 2003).

185. See LaSalle Nat'l Bank v. Duff \& Phelps Credit Rating Co., 951 F. Supp. 1071, 1096 (S.D.N.Y. 1996); In re Fitch, 330 F.3d at 110 (holding that Fitch did not deserve free speech protection when its services were client-driven and it was actively involved in structuring the underlying transactions); see also Commercial Fin. Servs. v. Arthur Andersen LLP, 94 P.3d 106, 113 (Okla. Civ. App. 2004); Nathan Koppel, Credit Raters Plead the First. Will It Fly?, WALL ST. J. (Apr. 21, 2009), https://www.wsj.com/articles/SB12402742711463 7327 [http://perma.cc/78PW-WD54] ("The more it looks like [ratings] firms were hired specifically to do this one rating for this one company ... the less likely it is that the First Amendment will be applied.") (quoting Larry Ellsworth, former litigator at the SEC). 
cial crisis. ${ }^{186}$ In several cases, courts issued judgments against the rating agencies. In others, the parties reached out-of-court settlements. The most significant settlement to date between the CRAs and a private claimant concerned the California Public Employee Retirement System (CALPERs). In 2015 and 2016, respectively, CALPERs settled with S\&P and Moody's for a combined total of $\$ 255$ million, representing the largest known recovery from S\&P and Moody's from a private lawsuit relating to damages from ratings. In litigating against CRAs, First Amendment arguments have been common, as we have seen in the previous section. However, they no longer provide an absolute shield to CRA liability.

\section{A. Investor Suits Against Rating Agencies}

In the wake of the global financial crisis, some investors sued CRAs for misrepresentation at common law. To date, no U.S. court has held a CRA liable to investors for misrepresentation or securities law violations. But there have been several important settlements.

In the common law fraud context, as articulated in the Restatement (Second) of Torts, opinions are defined as follows: "A representation is one of opinion if it expresses only (a) the belief of the maker, without certainty, as to the existence of a fact; or (b) his judgment as to quality, value, authenticity, or other matters of judgment." 187 Courts routinely cite this definition in misrepresentation cases. ${ }^{188}$ In the wake of the stock market crash of 2000 and the financial crisis of 2008, the issue surfaced in securities litigation concerning whether statements are factual assertions that amount to more than mere opinions. In addition to rating agency "opinions," defendants have argued that the opinions of securities-analyst and statements of corporate optimism are protected by the First Amendment. ${ }^{189}$

In one of the most significant lawsuits against CRAs to date, fourteen plaintiffs, led by Abu Dhabi Commercial Bank (ADCB), accused CRAs of negligent misrepresentation over their activities regarding two structured investment vehicles ${ }^{190}$ (Cheyne and Rhinebridge), claiming that the CRAs misled the plaintiffs about the true risk levels. ${ }^{191}$ They also alleged

186. Joel Rosenblatt \& Matt Scully, Moody's Settles Calpers Ratings Lawsuit for $\$ 130$ Million, BLOOMBERG (Mar. 9, 2016, 12:21 PM), http://www.bloomberg.com/news/articles/ 2016-03-09/calpers-says-moody-s-to-pay-130-million-to-settle-ratings-case.

187. Restatement (Second) of Torts § 538A (Am. Law Inst. 1977).

188. See, e.g., McEneaney v. Chestnut Hill Realty Corp., 650 N.E.2d 93, 96 (Mass. App. Ct. 1995); Consol. Papers, Inc. v. Dorr-Oliver, Inc., 451 N.W.2d 456, 459 (Wis. Ct. App. 1989); Marino v. United Bank of Ill., N.A., 484 N.E.2d 935, 937 (Ill. App. Ct. 1985). 2012).

189. City of Omaha Civilian Emps. Ret. Sys. v. CBS Corp., 679 F.3d 64, 68 (2d Cir.

190. A structured investment vehicle is a fund that borrows money by issuing shortterm securities at a low interest rate and then lends that money by purchasing long-term securities at higher interest.

191. Abu Dhabi Commercial Bank v. Morgan Stanley \& Co., 888 F. Supp. 2d 431, 460 (S.D.N.Y. 2012). 
conflict of interests stemming from the issuer-pays fee system that the rating agencies use, and claimed more than $\$ 700$ million in damages. The allegations very much resemble those by the U.S. Department of Justice in the suit against $\mathrm{S} \& \mathrm{P}$ (see next section) - i.e., fraudulently inflating ratings to win rating business. ${ }^{192} \mathrm{~S} \& \mathrm{P}$, in its defense, used similar arguments to those in its dispute with the U.S. Department of Justice, pointing to its First Amendment right to free speech.

The parties settled their dispute a week before trial, and the terms of the settlement remain confidential. ${ }^{193}$ It would have marked the first jury trial on the rating agencies' conduct before the financial crisis. In their public statements, all parties seemed to be satisfied with the settlement, especially the rating agencies, which try to avoid any litigation on their pre-financial crisis rating behavior. Moody's commented, "[t]his settlement allows us to put the significant legal defense and related costs, as well as the distraction, of these protracted litigations behind us. . . We are satisfied that it is in the best interests of our company and shareholders." 194 The official statement of ADCB states that it "is satisfied with the outcome of the settlement. The original investment had already been fully provisioned and receipt of the settlement process will have a positive but relatively limited impact on ADCB's balance sheet."195

In 2013, the District Court for the Southern District of New York struck out a claim against Moody's. The plaintiffs alleged that Moody's had made false statements about the independence and objectivity of its "issuer-pays" model of its credit ratings business. ${ }^{196}$ They further argued that Moody's had made numerous misrepresentations in its code of conduct, annual reports to its shareholders and other publications, concealing conflicts in its rating of structured finance securities. The court held that the plaintiffs failed to establish that the rating agency violated federal securities laws-specifically, §10(b) and $\S 20(a)$ of the Securities Ex-

192. See, e.g., Stephen Foley, Standard \& Poor's and Moody's Settle US Subprime Lawsuits, Fin. TIMES (Apr. 27, 2013), https://www.ft.com/content/27a59708-af46-11e2-ac6f00144feabdc0 [https://perma.cc/A88C-DRBF]; Jeannette Neumann, S\&P, Moody's Settle Ratings Lawsuit, WALl ST. J. (Apr. 26, 2013), https://www.wsj.com/articles/SB10001424127 887323789704578447561293487032 [https://perma.cc/493P-JFVC]; Antoine Gara, S\&P, Moody's Shares Surge on Fraud Lawsuit Settlement, TheStreet (Apr. 29, 2013, 4:48 PM), https://www.thestreet.com/story/11908039/1/sp-moodys-lingering-legal-risks.html [https:// perma.cc/8QXX-V9YD]; see also Letter from William J. Harrington to Elizabeth M. Murphy, Sec'y, Sec. \& Exch. Comm'n (May 29, 2014) (providing a remarkable analysis of inflated ratings in the SF market).

193. See Nate Raymond \& Jonathan Stempel, Moody's, S\&P settle lawsuits over debt vehicle ratings, REUTERS (Apr. 27, 2013, 7:21 PM), https://www.reuters.com/article/ moodys-sp-settlement-idUSL2N0DE00Q20130427 [http://perma.cc/AV8T-LUVF]; Hadeel al Sayegh, $A D C B$ ends legal battle with Morgan Stanley over soured investment, THE NATIONAL (Apr. 28, 2013), https://www.thenational.ae/business/adcb-ends-legal-battle-withmorgan-stanley-over-soured-investment-1.365077 [http://perma.cc/V3XR-26G5].

194. Sayegh, supra note 193.

195. Shane McGinley, UAE bank settles legal case with rating agencies, Arabian Bus. (Apr. 28, 2013), https://www.arabianbusiness.com/uae-bank-settles-legal-case-with-ratingagencies-499819.html [https://perma.cc/XXJ9-GWXB].

196. In re Moody's Corp. Sec. Litig., No. 07 Civ. 8375(GBD), 2013 WL 4516788, at*11 (S.D.N.Y. Aug. 23, 2013). 
change Act of 1934. The plaintiffs failed to show a sufficient causal link between the alleged misstatements and subsequent declines in Moody's share prices. None of the events listed that the plaintiffs losses were linked sufficiently closely to Moody's alleged misrepresentations to justify a securities fraud claim. The court concluded that "[p]laintiffs must proffer some evidence demonstrating that Moody's specific alleged misrepresentations caused the materialization of the risk that Moody's rating practices were unsustainable. They fail to do so." 197

In In re Lehman Bros. Securities and ERISA Litigation, investors who purchased mortgage pass-through certificates sued S\&P and Moody's under $\S \S 11,12(\mathrm{a})(2)$, and 15 of the Securities Act of 1933 for alleged misrepresentations, on the theory that CRAs could be sued as statutory underwriters, sellers, or control persons. The court dismissed these claims, holding that the rating agencies' alleged activities did not make them statutory underwriters, sellers, or control persons. ${ }^{198}$

Courts have refused some of these $\S 11$ claims based on SEC Rule 436(g)(1). As we saw above, Rule 436(g) of the Securities Act of 1933 granted a special type of immunity to CRAs. Yet Section 939G of the Dodd-Frank Act of 2010 repealed this rule, opening the way for future claims against CRAs. Accordingly, CRAs could now be liable for false ratings published in registration statements with the SEC for new offerings.

CRAs have also been sued on the ground that their misconduct fell within the scope of the False Claims Act, which allows private individuals to allege that the government has been defrauded. In Kolchinsky $v$. Moody's, ${ }^{199}$ Kolchinsky alleged that inflated ratings by Moody had damaged government programs. Kolchinsky was a former managing director of the derivatives group at Moody's. He claimed that Moody's retaliated when he disclosed his fears that Moody's was engineering credit ratings by using rating methods Moody's knew to be inappropriate or misleading. In 2016, Moody's brought a motion to dismiss. Moody's first argued that Kolchinsky had violated the False Claims Act himself by bringing a claim founded on allegations that he had publicly circulated. However, Kolchinsky rebutted that argument by successfully showing that he was the original source of the allegations. ${ }^{200}$ Kolchinsky had various possible theories about how Moody's had defrauded the government. However, Moody's

197. Id.

198. In re Lehman Bros. Sec. \& ERISA Litig., 681 F. Supp. 2d 495, 500 (S.D.N.Y. 2010). Other relevant cases considered in this research were Tsereteli v. Residential Asset Securitization Tr. 2006-A8, 692 F. Supp. 2d 387, 396 (S.D.N.Y 2010); In re Indymac Mortgage-Backed Sec. Litig., 718 F. Supp. 2d 495, 504 (S.D.N.Y. 2010); N.J. Carpenters Vacation Fund v. Royal Bank of Scotland Grp., PLC, 720 F. Supp. 2d 254, $263-64$ (S.D.N.Y. 2010); In re Wells Fargo Mortgage-Backed Certificates Litig., 712 F. Supp. 2d 958, 968-69 (N.D. Cal. 2010); Pub. Emps. Ret. Sys. of Miss. v. Merrill Lynch \& Co., 714 F. Supp. 2d 475, 484-85 (S.D.N.Y. 2010).

199. United States ex rel. Kolchinsky v. Moody's Corp., 162 F. Supp. 3d 186, 195 (S.D.N.Y. 2016).

200. Id. at 194. 
succeeded in dismissing four out of five of Kolchinsky's theories. ${ }^{201}$ Kolchinsky was given leave to refile on the remaining issue. Kolchinsky $v$. Moody's demonstrates that the False Claims Act is not a workable tool to tackle fraudulent ratings, as it requires a close link between fraudulence and reimbursement by a government program not evident in many ratings cases. ${ }^{202}$

The settlements between the CRAs and several private investors show how CRAs run a significantly higher risk of liability since the subprime crisis. Those settlements between S\&P, Moody's, and the U.S. Department of Justice have been momentous in the sense that both major CRAs agreed to make record payments to the governments in relation to their rating activity.

\section{B. The U.S. Government's Enforcement Actions Against Rating Agencies}

The Financial Institutions Reform, Recovery, and Enforcement Act of 1989 (FIRREA) provides for a novel civil cause of action against CRAs. ${ }^{203}$ Further, FIRREA lowers the standard of proof. ${ }^{204}$ When compared to the criminal standard of proof, FIRREA is a "walk in the park for government attorneys." 205 Claimants must prove only that the defendant committed one of FIRREA's predicate offenses by a "preponderance of the evidence" rather than to a criminal standard of "beyond reasonable doubt."206 FIRREA provides for criminal prosecution, but also allows the U.S. Attorney General to bring civil actions to recover civil penalties for several banking crimes. ${ }^{207}$ FIRREA provides for civil penalties, including $\$ 1$ million for one-time violations, and up to $\$ 5$ million for continuing violations of one of the underlying criminal statutes.

201. Id. at 200 .

202. This remains the case even after Universal Health Servs. v. United States ex rel. Escobar, 136 S. Ct. 1989 (2016). This decision represents a significant development for the False Claims Act because the Supreme Court confirmed in the context of pharmaceuticals that implied certification could form the basis for liability. However, the court stressed a high bar for materiality, requiring that compliance must be knowingly part of the government's payment decision, and stated that the FCA was now an all-purpose anti-fraud statute.

203. Financial Institutions Reform, Recovery and Enforcement Act of 1989, Pub. L. No. 101-73, 103 Stat. 183 (1989) (codified as amended at 12 U.S.C. \$1833(a) (2012)). See generally Nan S. Ellis et al., Use of FIRREA to Impose Liability in the Wake of the Global Financial Crisis: A New Weapon in the Arsenal to Prevent Fraud, 18 U. PA. J. Bus. L. 119 (2015).

204. Daniel B. Gail \& Joseph J. Norton, The Financial Institutions Reform Recovery and Enforcement Act of 1989: Dealing with Regulators, 107 BANking L.J. 196, 221 (1990).

205. Jay Williams et al., FIRREA: An Old Acronym Is Turning into the Government's New Hammer on Banks and Other Financial Institutions, 129 BANKING L.J. 579, 580 (2012).

206. 12 U.S.C. $\S 1833 a(f)$ (2012).

207. See Financial Institutions Reform, Recovery and Enforcement Act §§ 901-63. See Mary Kreiner Ramirez, The Science Fiction of Corporate Criminal Liability: Containing the Machine Through the Corporate Death Penalty, 47 ArIz. L. Rev. 933, 943 (2005); see also Vikramaditya S. Khanna, Politics and Corporate Crime Legislation, 27 Regulation 30, 30 (2004) (observing that corporations would prefer criminal legislation to civil suits because there is greater private civil enforcement and higher criminal procedural standards). 
The criminal penalties available are in addition to the civil penalties, which may be recovered by the federal banking agencies, as well as to any criminal fines imposed for the same offenses. Finally, unlike the threeyear to five-year statute of limitations under typical state civil fraud statutes, FIRREA carries a ten-year statute of limitations. ${ }^{208}$ Many recent FIRREA complaints filed in the last years sought relief under both the False Claims Act ("FCA") and FIRREA. 209

In 2013, the U.S. Department of Justice (as well as nineteen states and the District of Columbia) ${ }^{210}$ claimed civil penalties under FIRREA against S\&P for allegedly defrauding investors out of $\$ 5$ billion in mortgage-related securities. ${ }^{211}$ They claimed civil penalties amounting to a sum of $\$ 5$ billion from S\&P for “(a) mail fraud affecting federally insured financial institutions; (b) wire fraud affecting federally insured financial institutions; and (c) financial institution fraud." 212 The claimants alleged that the ratings depicted an incorrect picture of the market, portraying the securities as much safer than they in fact were:

S\&P, knowingly and with the intent to defraud, devised, participated in, an executed a scheme to defraud investors in RMBS and CDO tranches, including federally insured financial institutions, as to material matters, and to obtain money from these investors by means of material false and fraudulent pretenses, representations and promises, and the concealment of material facts. ${ }^{213}$

It allegedly "limited, adjusted, and delayed updates to the ratings criteria and analytical models S\&P used to access the credit risks," and

knowing that the credit risks of certain non-prime RMBS tranches were increasing, were expected to continue to increase, and were anticipated to result in negative Rating Actions . . . knowingly disregarded the true extent of the credit risks associated with those nonprime RMBS tranches in issuing and/or confirming ratings for CDOs

208. 12 U.S.C. $\$ 1833 \mathrm{a}(\mathrm{h})(2012)$.

209. See, e.g., United States v. Americus Mort. Corp., No. 8:12-cv-02676, 2013 WL 4829271 (S.D. Tex. Sept. 10, 2013); United States v. Luce, No. 11-cv-5158, 2012 WL 2359357 (N.D. Ill. June 20, 2012); Complaint, United States ex rel. Hunt v. CitiMortgage, No. 1:11-cv-5473(VM) (S.D.N.Y. Feb. 15, 2012); Complaint, United States v. Buy-AHome, LLC, No. 10-cv-9820 (S.D.N.Y. Dec. 13, 2010), 2010 WL 5415787. On the litigation against CRAs under the False Claims Act, see cases included in this note.

210. The states include Arizona, Arkansas, California, Connecticut, Colorado, Delaware, Idaho, Illinois, Indiana, Iowa, Maine, Mississippi, Missouri, New Jersey, North Carolina, Pennsylvania, South Carolina, Tennessee, and Washington.

211. To our knowledge, the Department of Justice was the first plaintiff to sue a CRA under FIRREA. Tom Wicker, US Department of Justice prosecutes Standard \& Poor's as tide turns against ratings agencies, INT'L BAR Ass'N (Mar. 7, 2013), https://www.ibanet.org/ Article/NewDetail.aspx?ArticleUid=af324fa2-7e0c-4ce8-89f0-e5e4bcd86827 [https://perma .cc/L5YT-NY58]. Ironically, the U.S. Department of Justice decided to claim civil penalties under FIRREA against S\&P, whereas FIRREA referred to NRSRO ratings to force the savings and loan industry to reduce the riskiness of its asset portfolios. See Alex M. Azar, FIRREA: Controlling Savings and Loan Association Credit Risk Through Capital Standards and Asset Restrictions, 100 Y ALE L.J. 149, 162-63 (1990).

212. Complaint \& Demand for Jury Trial at II 1, United States v. McGraw-Hill Cos., 302 F.R.D. 532 (C.D. Cal. Aug. 1, 2014) (No. CV 13-00779-DOC (JCGx)).

213. Id. II 7. 
with exposure to those non-prime RMBS tranches. ${ }^{214}$

Accordingly, S\&P misled investors by the erroneous RMBS and CDO ratings, which did not represent S\&P's true opinion on their creditworthiness at the time.

The alleged motive for such positive ratings and the downplaying of the true extent of the credit risks posed by RMBS and CDO tranches was a desire to increase business with large investment banks, which would thereby boost S\&P's market share for credit ratings of RMBS and CDOs. ${ }^{215}$ Crucial to this incentive structure is the "issuer pays" model. As a result of S\&P's conduct, federally insured financial institutions invested in RMBS and CDO tranches that were assigned high ratings and consequently suffered financial loss when the true risk level materialized.

S\&P invoked its First Amendment right to criticize the government. It rejected the claimant's allegations and saw the suit as a form of payback for the rating agency's decision to downgrade the United States' rating from AAA to AA+ in 2011. ${ }^{216}$ It alleged that the Department of Justice singled out S\&P due to its downgrade of the U.S. market, while they left untouched all other major rating agencies that had also misrated securities in the relevant period. The case of Egan Jones, which also downgraded the U.S. and was later investigated by U.S. authorities, might substantiate S\&P's allegation. ${ }^{217}$ Credit risk expert Marc Joffe pointed out that "both [Egan Jones and S\&P] downgraded the U.S. and subsequently faced disciplinary action from the U.S. government. Perhaps this helps explain why Moody's chose to downgrade the U.K. while leaving the US at Aaa." 218 Others argue that the Justice Department only sued $\mathrm{S} \& \mathrm{P}$ - or sued it first-because (1) it is the world's biggest rating agency and (2) there was a considerable paper trail indicating guilt on the part of S\&P. ${ }^{219}$

214. Id. II 124.

215. In its submissions, the U.S. Department of Justice refers to various internal correspondences within S\&P indicating the intention to keep ratings high to win rating assignments.

216. For such an implied allegation, see United States v. McGraw-Hill Cos., No. CV 13779-DOC (JCGx), 2014 WL 1647385, at*12 (S.D. Cal. Apr. 15, 2014) (citing the Declaration of Harold McGraw, the CEO of McGraw-Hill); see also Edvard Pettersson, Geithner Said U.S. Would Respond to Downgrade, S\&P Says, Bloomberg (Jan. 22, 2014, 8:05 PM), https://www.bloomberg.com/news/articles/2014-01-21/geithner-said-u-s-would-respond-todowngrade-s-p-says.

217. See Press Release, SEC, Egan-Jones Ratings Co. and Sean Egan Charged with Making Material Misrepresentations to SEC (Apr. 24, 2012), https://www.sec.gov/news/ press-release/2012-2012-75htm; Press Release, SEC, Egan-Jones and Founder Sean Egan Agree to 18-Month Bars from Rating Asset-Backed and Government Securities Issuers as NRSRO (Jan. 22, 2013), https://www.sec.gov/news/press-release/2013-2013-7htm.

218. Marc Joffe, Moody's, S\&P and other credit rating agencies deserve a failing grade, GuARDiAn (Feb. 25, 2013, 4:30 PM), https://www.theguardian.com/commentisfree/2013/ feb/25/moodys-sp-credit-rating-agencies-need-reform [https://perma.cc/2UVW-AYQX].

219. Aruna Viswanatha \& Luciana Lopez, Justice Department, states weigh action against Moody's, ReUTERs (Feb. 7, 2013, 6:22 PM), https://www.reuters.com/article/usmoodys-investigation/justice-dept-states-weigh-action-against-moodys-idUSBRE916185 20130208 [https://perma.cc/2W2L-GKK9]. 
The U.S. Department of Justice and McGraw-Hill Financial, alongside nineteen states and the District of Columbia, settled on February 3, 2015 for $\$ 1.375$ billion. According to then-Attorney General Eric Holder, under the settlement, S\&P conceded that "company executives complained that the company declined to downgrade underperforming assets because it was worried that doing so would hurt the company's business." 220 It did not, however, admit to violating any laws. The CRA withdrew its allegations that the United States' FIRREA complaint against it was a retaliatory measure because of S\&P's 2011 decision to place the U.S. on credit watch negative and following downgrade of its credit rating. 221

In September 2016, the U.S. Department of Justice stated that it prepared a civil complaint to be filed against Moody's in the U.S. District Court for the District of New Jersey, alleging certain violations of the FIRREA in connection with the ratings Moody's assigned to RMBS and CDO prior to 2008. The Department of Justice also stated that its investigations could expand. Several states' attorneys general indicated they intended to pursue similar claims under state law.222 This civil complaint is not so surprising: Phil Angelides, who led the bipartisan Financial Crisis Inquiry Commission that published a report in 2011, said that what they found at Moody's "was very similar to the practices and conduct at Standard \& Poor's. The conduct and results were the same." 223 Finally, on January 13, 2017, the "Department of Justice, 21 states, and the District of Columbia reached a nearly $\$ 864$ million settlement agreement with Moody's."224

The SEC, as the market regulator, has also launched enforcement actions against CRAs. In the first-ever enforcement action against a major rating agency, the SEC fined S\&P a total of $\$ 77$ million. ${ }^{225}$ The action dealt with six commercial mortgage-based securities (CMBS) that S\&P rated in 2011. Similar to the Justice Department's suit against S\&P, the

220. Press Release, Dep't of Justice, Justice Department and State Partners Secure $\$ 1.375$ Billion Settlement with S\&P for Defrauding Investors in the Lead Up to the Financial Crisis (Feb. 3, 2015), https://www.justice.gov/opa/pr/justice-department-and-state-part ners-secure-1375-billion-settlement-sp-defrauding-investors.

221. S\&P near $\$ 1$ bn deal to settle US subprime suit, Daily MaIL (Jan. 16, 2015), http:// www.dailymail.co.uk/wires/afp/article-2914045/S-P-near-1-bn-deal-settle-US-subprime-suit .html [https://perma.cc/T9AZ-2YWG].

222. Moody's Corp., Current Report (Form 8-K) (Oct. 21, 2016) (discussing in "Litigation Update" states attorneys general intention to pursue claims under state).

223. Timothy W. Martin, Justice Department Investigating Moody's Investors Service, WALl ST. J. (Feb. 1, 2015), https://www.wsj.com/articles/justice-department-investigatingmoodys-investors-service-1422822296 [https://perma.cc/G5WP-KUR6].

224. Press Release, Dep't of Justice, Justice Department and State Partners Secure Nearly \$864 Million Settlement With Moody's Arising From Conduct in the Lead up to the Financial Crisis (Jan. 13, 2017, 8:37 PM), https://www.justice.gov/opa/pr/justice-departmentand-state-partners-secure-nearly-864-million-settlement-moody-s-arising.

225. This consisted of $\$ 58$ million to settle the SEC charges, $\$ 12$ million to the New York Attorney General's Office, and \$7 million to the Massachusetts Attorney General's office to settle parallel cases. See Press Release, SEC, SEC Announces Charges Against Standard \& Poor's for Fraudulent Ratings Misconduct (Jan. 21, 2015), https://www.sec.gov/ news/pressrelease/2015-10.html. 
SEC claimed that the rating agency had fraudulently bent criteria to win more business. According to the SEC, it "elevated its own financial interests above investors by loosening its rating criteria to obtain business and then obscuring these changes from investors." 226 The SEC furthermore banned S\&P from rating such bonds for a period of one year. However, the effect of the ban on S\&P was minimal, as it was limited to the rating of loans to multiple borrowers-a sector in which S\&P accounted for only $9 \%$ of the deals in $2014 .^{227} \mathrm{~S} \& \mathrm{P}$ could continue to rate single-borrower CMBS, a market in which the rating agency rates $82 \%$ of all offerings.

Additionally, the SEC also pursued administrative proceedings against the former head of S\&P's CMBS Group, Barbara Duka, for fraudulent misrepresentation in relation to the manner in which the rating agency calculated an aspect of certain CMBS ratings in 2011.228 Duka responded by contending that the SEC proceedings were constitutionally defective and fought to have her case heard in a federal court. Duka succeeded and the SEC proceedings were frozen. The SEC initially looked to appeal but in 2016 dropped its appeal. ${ }^{229}$

It is noteworthy that CALPERs sued both Moody's and S\&P related to allegedly negligent misrepresentations under California law in connection to the ratings of three structured investment vehicles in which CALPERs invested $\$ 1.3$ billion. A 2014 Californian Appeals Court decision denying the rating agencies' motion to strike out likely prompted the settlement, as the claimants had made a prima facie case of negligent misrepresentations. ${ }^{230}$ Further, the court rejected the agencies' allegation that the case should be dismissed on First Amendment grounds; the court considered that credit ratings issued in relation to a structured investment vehicle were only issued in relation to a limited class of investors. Therefore, they were not of public concern and not did not warrant actual malice protection. The judge considered that it would be premature, however, to de-

226. Id.

227. Matt Robinson \& Sarah Mulholland, S\&P Ban Leaves Debt Rater Unharmed in Most of Its CMBS Business, Bloomberg (Jan. 23, 2015, 2:27 PM), https://www.bloomberg .com/news/articles/2015-01-23/s-p-ban-leaves-debt-rater-unharmed-in-most-of-its-cmbsbusiness.

228. See SEC Announces Charges, supra note 225; In re Duka, Order Instituting Administrative and Desist Proceedings, Securities Act Release No. 9706, Exchange Act Release No. 74,105, Investment Company Act Release No. 31,425, 2015 WL 252449, at *2 (Jan. 21, 2015).

229. See Nate Raymond, Ex-S\&P exec sues U.S. SEC ahead of administrative Charges, Reuters (Jan. 17, 2015, 5:21 PM), http://www.reuters.com/article/sec-mcgraw-hill-fin-lawsuit-idUSL1N0UV2HC20150116 [https://perma.cc/5ERB-VEL7]; Duka v. SEC, 103 F. Supp. 3d 382, 386 (S.D.N.Y. 2015); Al Yoon, S\&P Removes CMBS Ratings Chief, WALL ST. J. (Feb. 3, 2012), http://blogs.wsj.com/developments/2012/02/03/report-sp-removescmbs-ratings-chief [https://perma.cc/Z8JM-UVG4]; Standard \& Poor's, Berated: A rating agency makes a grudging concession, THE ECONOMIST (Jan. 24, 2015), https://www.econo mist.com/finance-and-economics/2015/01/22/berated [https://perma.cc/37ZG-UENG].

230. Cal. Pub. Emps. Ret. Sys v. Moody's Invs. Serv., Inc., 172 Cal. Rptr. 3d 238, 247 (Cal. Ct. App. 2014). 
cide the First Amendment point. ${ }^{231}$ In February 2015, CALPERs and S\&P reached a settlement worth $\$ 125$ million. Similarly, in March 2016, Moody's settled with CALPERs for $\$ 130$ million. ${ }^{232}$

The settlements that Moody's and S\&P had to consent to during 2013-2017 reflect the increasing fragility of the First Amendment protection. In fact, CRAs lost their "quasi-immunity" because the nature of their ratings changed substantially in the 1990s-2000s. The subprime crisis served as a catalyst; the lawsuits that followed obliged Moody's and $\mathrm{S} \& \mathrm{P}$ to admit that their ratings are no longer regarded, by default, as opinions.

\section{CONCLUSION}

On the eve of the mortgage market crisis of 2007, CRAs were less liable and more powerful than ever. They experienced a quasi-immunity regime in the United States and Europe. Most investors used their ratings, and many regulatory rules incorporated ratings. In 2008-2011, the investigations and hearings that the SEC and the U.S. Senate held established that ratings had serious shortcomings, which upset the credit rating business. First, starting in 2010, U.S. and European legislators and regulators cut overreliance on credit ratings. ${ }^{233}$ This new pattern was a major shift for U.S. investors, as the OCC enacted the first regulatory rule incorporating credit ratings in 1931. Second, CRAs have faced more and more lawsuits since the late 2000s.

In fact, we argue in this article that CRAs lost their regulatory and judicial "quasi-immunity" over the last decade, partly as a result of their behavior in the lead-up to the subprime crisis. CRAs succumbed to the "Icarus Syndrome," believing that they were above the law, shielded by the First Amendment from potential liability for ratings. CRAs enjoyed "quasi-immunity" as long as they assigned their ratings in the interest of investors and the courts considered them protected speech under the First Amendment. Historically, U.S. courts have considered ratings as opinions on matters of public concern, and therefore as protected speech under the First Amendment. CRAs have long argued that they are like members of the financial press, their ratings being akin to a short editorial. In some cases, the courts have effectively treated CRAs as part of the media industry. For most of the post-World War II period, U.S. courts were unanimous on the qualification of ratings as free speech.

This quasi-immunity was also a deterrent for litigation against CRAs ex ante. Precisely because the First Amendment protection for CRAs was impregnable and widely accepted, the number of court decisions upholding the rule that CRAs benefited from First Amendment protection was

231. Id. at 265 .

232. Fitch settled negligence claims by CALPERs in 2011, however, without making any payment to CALPERs.

233. See Norbert J. Gaillard, Coping with Reliance on Credit Ratings, 35 BANKING \& Fin. Servis. Pol'y Rep. 12, 12 (2016). 
small. An additional reason for the paucity of litigation against CRAs prior to the shift to the issuer pays model in the 1970s was that investors were not in privity with the CRA. Investors faced the fundamental obstacle that they themselves did not subscribe to the ratings, and thus had no contract with CRAs.

When CRAs shifted their business model and began to charge issuers for ratings, and assigned their ratings in the interest of specific business audiences (i.e., the investment banks that issued SF products, rather than investors), U.S. courts increasingly came to regard their ratings and reports as commercial speech. We argued that the once impenetrable shield that CRAs enjoyed in U.S. court-thanks to the First Amendment-has eroded since the subprime crisis of 2007-2008. Increasingly, courts came to regard ratings as mere commercial speech that did not touch public concerns - in contrast to the heightened constitutional protection for political free speech under the First Amendment.

Courts have pared back the quasi-immunity that CRAs previously enjoyed from two different directions. Traditionally, courts considered ratings to be free speech protected by the First Amendment. As a result of several developments such as the shift from the "investor pays" to the "issuer pays" model, the development of ancillary business, the issuance of structured finance ratings, and the existence of growing conflicts of interest, courts increasingly denied First Amendment protection to CRAs. In addition, allegations of negligent misrepresentation and other fraudulent behavior, as the SEC and the U.S. Senate established, provided investors with more grounds to sue CRAs and to reach advantageous settlements. In 2015, after the U.S. Department of Justice sued S\&P, the firm settled claims that it inflated its SF ratings to preserve its market shares and defraud investors for $\$ 1.375$ billion.

Although recent cases and settlements support the view that Fitch, Moody's, and S\&P failed as gatekeepers of financial markets, the new liability regime that is emerging remains lenient. Besides, debt issuers are still dependent on credit ratings, and finding simple and robust substitutes to credit ratings is tricky. This suggests that law and regulation may be unable to curb some deep-rooted market practices, even when such practices have had calamitous consequences for investors, taxpayers, and the public. Without further reform and innovation, it is likely that CRAs will again fail to act as gatekeepers in the lead-up to the next major financial crisis. 